\title{
Corrosion of Chromium-Rich Oxide Refractories in Molten Waste Glasses
}

\author{
Final Report
}

Prepared by

Hao Gan, Xiaodong Lu, Andrew C. Buechele, M. Catherine Paul, and Ian L. Pegg

\author{
Vitreous State Laboratory \\ The Catholic University of America \\ Washington, DC
}

For

The Department of Energy

Mixed Waste Focus Area

Idaho Falls, ID

March 20, 2002 


\section{Table of Contents}

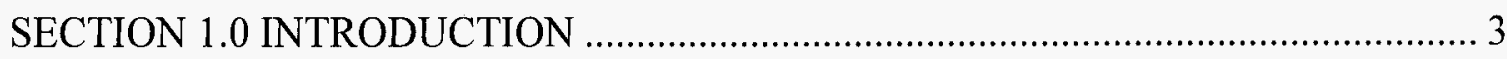

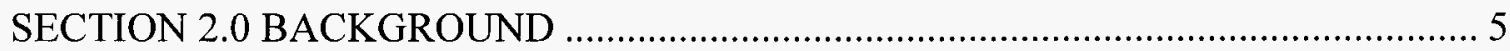

SECTION 3.0 EXPERIMENTAL METHOD …………............................................. 7

3.1 Standard Refractory Coupon Corrosion Test ................................................... 7

3.1.1 Sample Preparation ................................................................................ 7

3.1.2 Refractory Corrosion Test............................................................................ 8

3.1.3 Characterization of the Reacted Test Coupons and Glasses........................... 8

3.2 Granular Refractory Dissolution Experiments …………................................... 9

3.3 Crystallization Experiment of $\mathrm{Cr}$-rich Spinel from the Glass Melts .................... 9 SECTION 4.0 COMPARATIVE STUDY OF THE CORROSION RATES OF SEVERAL HIGH CHROMIUM OXIDE REFRACTORIES .......................................... 10

4.1 Chromium-Rich Oxide Refractory Bricks........................................................ 10

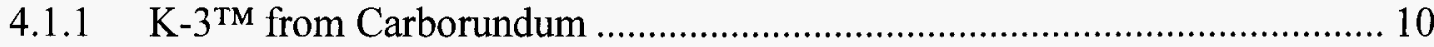

4.1.2 ETM from Carborundum ...................................................................... 11

4.1.3 ER-2161 by Cohart ................................................................................. 11

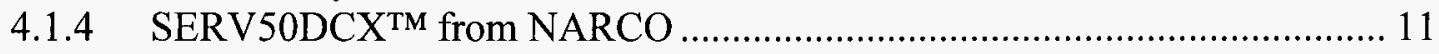

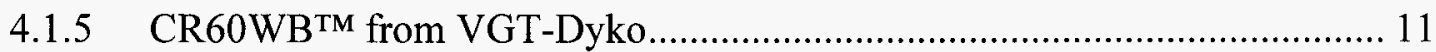

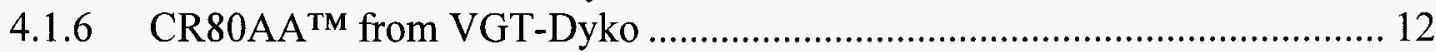

4.2 Results of Glass Contact Corrosion and Discussion ........................................... 12

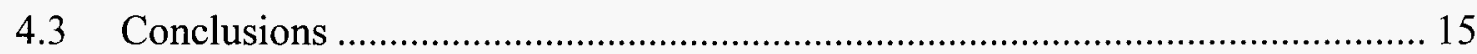

SECTION 5.0 CONTROLLING FACTORS FOR K-3 CORROSION IN …….............. 17

HIGH-SODIUM WASTE GLASS MELTS ......................................................... 17

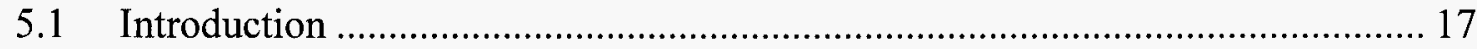

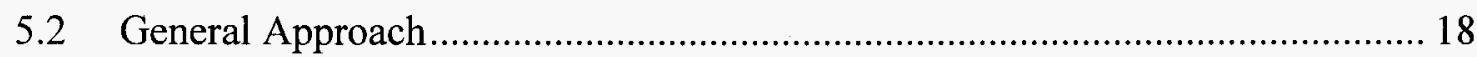

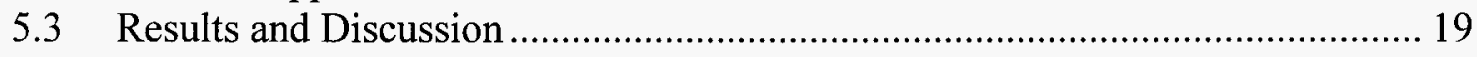

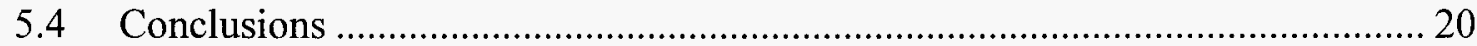

SECTION 6.0 K-3 GLASS CONTACT CORROSION OF SELECTED GLASSES .... 21

6.1 K-3 Corrosion in Hanford High-Level Waste Glass at 1208, 1283 and $1389^{\circ} \mathrm{C} 21$

6.2 K-3 ${ }^{\mathrm{TM}}$ Corrosion of Two Reference glasses (WVDP and SRL-EA) ................... 21

SECTION 7.0 REFERENCES ………………………........................................ 22 


\section{SECTION 1.0 INTRODUCTION}

The DOE is faced with a wide variety of waste treatment problems throughout the complex. The diversity in physical, chemical, and radiological characteristics of these waste streams will necessitate an array of treatment technologies since, at present, there exists no single solution. Thermal treatment technologies have an important, but by no means singular, role to play in addressing this problem since they generally offer the potential for significant volume reductions, leach resistant waste forms, considerable versatility, and are relatively well developed.

In particular, DOE has made significant investments in the development and deployment of vitrification technologies for the treatment of high-level nuclear wastes and, more recently, for mixed wastes. The general area of materials of construction is especially important for thermal processes due to the inherently high-temperature and the often-corrosive environments involved. The performance of these materials directly impacts treatment costs since this determines maintenance downtime and the useful service life of the treatment unit.

Molten glass at high temperatures is a corrosive liquid. In fact, this characteristic permits the rapid digestion and incorporation of the waste stream that is fed to the vitrification system. This places particularly severe demands on the glass contact refractories that are used to line vitrification systems. The material of choice for this application has been a $\mathrm{Cr}-\mathrm{Mg}-\mathrm{Al}-\mathrm{Fe}$ oxide fused-cast ceramic (Carborundum $\mathrm{K}-3^{\mathrm{TM}}$ ) that was selected nearly twenty years ago for the US high-level Joule-heated ceramic melters at Savannah River DWPF and West Valley WVDP. The same material has been used in several commercial melter systems for mixed waste vitrification supplied by Duratek, Inc., including the M-Area mixed waste vitrification system at Savannah River. While this material appears to have performed well at WVDP, its performance with mixed wastes was significantly below expectations at the M-Area facility and there are indications of similar faster-than-expected corrosion at DWPF. It is clear, and should not be surprising, that the corrosion rate of this and other refractory materials depends strongly on the composition of the glass melt; a refractory that is compatible with one glass composition range (e.g., high-level waste glasses) may be a not-so-good choice for another composition range (e.g., mixed waste glasses). The application of vitrification to mixed wastes will necessitate a wider range of glass compositions than has been investigated for the high-level wastes at DWPF and WVDP and there is, therefore, a significant gap in information on the performance of potential refractory materials for many of the applications for which vitrification is being considered. 
This issue is common to all refractory-lined vitrification systems including Joule, plasma, arc, and combustion melters. In the many years since the selection of $\mathrm{K}-3^{\mathrm{TM}}$ for the US high-level vitrification programs, many new refractories have been introduced for which there exists little data on waste glass compatibility. In addition, pre-existing refractories that were screened out for high-level wastes may actually be preferred for mixed waste vitrification due to the differences in glass compositions. A comparative corrosion test of a variety of oxide refractory materials should help to address this concern. Moreover, it is important to emphasize that the selection of a refractory material cannot be separated from the development of the waste glass since the glass-contact corrosion is simply the result of the interaction between the refractory and glass melts. Obviously, the glass chemistry would play a key role in material selection and corrosion control. Understanding the mechanism and the controlling factors of the refractory glasscontact corrosion is therefore of great practical importance for development of a longservicing-life vitrification system.

The objectives of this work are two-fold: 1) To provide comparative data on the corrosion of potential refractory materials against a representative waste glass; and, 2) To investigate the dominant processes that control the corrosion outcome and the parameters that could influence the corrosion rate. 


\section{SECTION 2.0 BACKGROUND}

Refractory glass contact corrosion is a common problem for the glass industry. Among the various methods of testing the corrosion rate of refractory bricks, the smallscale crucible-coupon corrosion test is the most efficient way to compare the corrosion resistance of refractory materials to a given glass melt. Previous experience gained from extensive corrosion tests conducted at the Vitreous State Laboratory of The Catholic University of America (CUA-VSL) has shown that carefully designed and executed coupon tests provide a great deal of detailed and useful information on corrosion rates, corrosion reactions, and structural alteration [1]. Perhaps more importantly, such coupon tests can also provide information that may lead to the selection or development of a better refractory material for waste glass melter applications [2, 3, 4, 5]. Research and development efforts completed in recent years at CUA-VSL for the M-Area DuraMelter at Savannah River and the LAW and HLW vitrification facility of the DOE Hanford site have demonstrated that the crucible-scale corrosion test provided crucial information for the design and construction of the vitrification facility $[6,7]$.

Many factors contribute to the corrosion resistance of a refractory material. For instance, the bulk composition and the phase assemblies of a refractory brick, the textures of the materials, including grain sizes and their distribution, porosity, and the manufacturing method (e.g., fused-cast, and hot-press-bonded, etc.) are key factors in determining corrosion resistance. It was a common perception in the refractory industry that for oxide refractory materials, a higher chromium content usually translates to a lower corrosion loss perhaps mainly because of the unusually low solubility and high thermal stability that were commonly observed for chromium oxide in regard to the typical commercial glass melts. A larger grain size was also considered better to resist the attack of the corrosive molten glass. In addition, other refractory oxides such as $\mathrm{Al}_{2} \mathrm{O}_{3}$, and $\mathrm{ZrO}_{2}$ can also play key roles in high temperature glass contact corrosion. It is thus sensible to perform comparative corrosion tests for refractory materials of various contents of $\mathrm{Cr}_{2} \mathrm{O}_{3}, \mathrm{Al}_{2} \mathrm{O}_{3}$ and $\mathrm{ZrO}_{2}$, different grain structure and phase assemblies, and manufacturing methods. Accordingly, the first part of this document reports the result of the comparative refractory corrosion tests in a representative waste glass.

For a given refractory and test conditions, our previous work has shown that the glass formulation is the focal point for the corrosion control of the refractory. Questions that must be answered relate to the mechanisms of the glass-refractory reactions and the key parameters that determine the corrosion rate. Conceivably, a series of corrosion experiments tested at different conditions would be needed to investigate, for instance, the thermodynamic and kinetic aspects of the corrosion process of interest. Accordingly, the second part of this report summarizes results from experiments on a selected 
refractory material (from the comparative tests) and discusses the mechanism of the refractory-glass reaction and the methods of refractory corrosion control. 


\section{SECTION 3.0 \\ EXPERIMENTAL METHOD}

The experimental methods used in this work include the standard refractory coupon corrosion tests, which are the established screening test methods developed at VSL, and the dissolution and crystallization method designed in this work to further elucidate the controlling processes for refractory-glass reactions. The standard refractory coupon corrosion test procedure was employed originally for the glass development work for the Savannah River M-Area facility and subsequently for the Hanford River Protection Project over the past several years and proved effective in providing the comparative data for evaluation of the refractory corrosion rate. The dissolution and crystallization experiment methods are standard reversal experiments used in phase equilibrium studies. The experimental methods are described below.

\subsection{Standard Refractory Coupon Corrosion Test}

The corrosion tests on refractory brick coupons were performed following a modified version of the ASTM C-621-84 procedure [8]. The test method involves sample coupon preparation, coupon corrosion under controlled conditions, and characterization of the reacted sample.

\subsubsection{Sample Preparation}

\subsubsection{Refractory Coupon Preparation}

The refractory test coupons used in this work were cut from commercial-size bricks supplied by the refractory manufacturers. Efforts were made to section the refractory coupons within one inch of the brick surface. All sides of the refractory coupons were then ground parallel with a precision of better than 1 mil. (0.001"). A typical test coupon measured 0.395 by 0.595 inches in cross-section and was long enough to be immersed in the molten glass to a depth of 1 inch (Figure 3.1). The finished test coupon was cemented to a piece of Zirmul wafer using Zirmul powder, dried at room temperature, and fired at $1200^{\circ} \mathrm{C}$ before testing. Once the mounted K-3 coupon was positioned inside the $200 \mathrm{ml}$ $\mathrm{Pt}$ crucible, the bottom of the coupon was about 0.2 inches from the bottom of the crucible. 


\subsubsection{Glass Preparation}

All glasses used in the corrosion tests were made by fusing the appropriate amounts of well-mixed chemicals in Pt crucibles at $1200^{\circ} \mathrm{C}$ in batches of 300 to 400 grams, followed by pouring the melts onto a cold graphite plate. The melting and homogenizing processes typically required one hour with the help of mechanical stirring with a $\mathrm{Pt} / \mathrm{Rh}$ stirrer. The glasses were routinely examined visually for any undissolved chemicals or possible crystallization. All of the glass compositions were analyzed by direct current plasma emission spectroscopy (DCP-ES) after total acid digestion or by x-ray fluorescence (XRF) on the solid glass.

\subsubsection{Refractory Corrosion Test}

All coupon corrosion tests were conducted using a modified ASTM refractory corrosion procedure [8] with the experimental arrangement shown schematically in Figure 3.2. The modifications were developed in earlier work performed at CUA-VSL for the M-Area glass development. For each test, a monolithic test coupon of known dimensions was first cemented to a crucible cover made of Zirmul, and then positioned in a $200 \mathrm{ml}$ Pt-crucible containing 170 grams of pre-fused glass. The coupon and the crucible inside a quartz crucible holder were then placed in a box furnace preheated to about $800^{\circ} \mathrm{C}$. After the furnace reached the designated temperature (normally $1208^{\circ} \mathrm{C}$ ), a Pt-bubbling tube was introduced into the molten glass from above through a slot in the Zirmul cover. For the standard air-bubbled corrosion tests, dry air was bubbled through the molten glass at a constant rate, controlled by a precision flowmeter, at $8 \mathrm{cc} / \mathrm{min}$ at room temperature. The bubbling rate, i.e., the number of the gas bubbles generated inside the melt per minute, was monitored using a pressure transducer interfaced to a computer via an $\mathrm{A} / \mathrm{D}$ converter board. The temperature of the furnace was monitored using an $\mathrm{S}$ type thermocouple positioned above the crucible inside the furnace. What we will refer to herein as the "standard" glass-contact corrosion test was run for six days with continuous gas bubbling at $1208^{\circ} \mathrm{C}$ at the refractory surface area $(\mathrm{S}) /$ melt volume $(\mathrm{V})$ ratio of about $0.20 \mathrm{~cm}^{-1}$, which is $74 \%$ less than the $\mathrm{S} / \mathrm{V}$ ratio specified by the ASTM C-621-84 for static glass contact corrosion tests. Fresh refractory test coupons were used for each corrosion test. At the end of each corrosion test, the coupon was removed from the melt and cooled to room temperature in a clean quartz crucible. The glass melt was poured into a graphite mold and cooled before further analysis.

\subsubsection{Characterization of the Reacted Test Coupons and Glasses}

After each corrosion test, the test coupons were sectioned at the mid-point and examined using an Olympus stereomicroscope for corrosion characteristics (e.g., morphology of new, modified, and original crystals, the texture of the reacted refractory, etc.). The corrosion loss of a refractory coupon was calculated from thickness 
measurements of the reacted coupon using a measuring microscope with a precision of better than 0.05 mil. Typically, eight or nine transverse lines were measured perpendicular to the length of the K-3 coupon. The dimension loss was calculated as half of the difference of the measured widths between the original coupon and the reacted coupon at the neck (glass-air interface) and at the half-down (the midpoint between the glass surface and the lower end of the coupon) (Figure 3.3). The errors associated with the measurements are small (less than 0.1 mil) because of the instrument precision and the regular shape of the reacted coupons below the melt line. Scanning electron microscopy (SEM) coupled with EDS was also used to characterize the reacted refractory coupons. Glass chemical compositions before and after the corrosion tests were analyzed by direct current plasma emission spectroscopy (DCP) and/or X-ray fluorescence spectroscopy (XRF).

\subsection{Granular Refractory Dissolution Experiments}

The powder dissolution experiments were conducted at 1208 and at 1283EC. About 6 grams of granular K-3 (particle size of $150 \mu \mathrm{m}$ or less) and 100 grams of glass were used for each of the powder dissolution experiments. The mixture of the K-3 refractory powder and glass was heated to the designated temperatures in a box furnace. The reacted K-3 grains and glass melts were dip-sampled using an alumina rod and quenched in cold water after $1,3,6,7$, and 10 days. The coexisting crystalline and glass material were then polished and analyzed by SEM/EDS to determine the composition of the glass and the near-surface refractory.

\subsection{Crystallization Experiment of Cr-rich Spinel from the Glass Melts}

Crystallization of $\mathrm{Cr}$-rich spinel from over-saturated waste glass melts was monitored at $1208^{\circ} \mathrm{C}$. For each experiment, about 1.5 grams of reagent-grade $\mathrm{Cr}_{2} \mathrm{O}_{3}$ powder was mixed with about 100 grams of the base glasses. The mixture was then loaded into a $\mathrm{Pt}$ crucible and heated to the experiment temperature. The progress of the crystallization of Cr-rich spinel was monitored by analyzing (by SEM-EDS) the compositions of the glass and coexisting crystalline phases that were dip-sampled after 3 and 6 days of continuous reaction. 


\section{SECTION 4.0 \\ COMPARATIVE STUDY OF THE CORROSION RATES OF SEVERAL HIGH CHROMIUM OXIDE REFRACTORIES}

Six chromium-rich oxide refractory bricks were been selected for the comparative corrosion study. Two of the six are from Carborundum: K-3 ${ }^{\mathrm{TM}}$, the refractory materials of choice in the last two decades for lining ceramic waste glass melters, and $E^{\mathrm{TM}}$, a higher$\mathrm{Cr}$ and higher-spinel variation of $\mathrm{K}-3^{\mathrm{TM}}$. One refractory is from Corhart, ER2161, a high Cr-type AZS refractory that was used in the German/Belgian PAMELA HLW vitrification facility. All three refractory bricks are fused-cast materials with relatively low porosity. Three bonded-hot-pressed refractory bricks were included in this comparative study. Two are from VGT-Dyco, CR60WB and CR80AA, which have high $\mathrm{Cr}$ contents and larger grain size. One is from NARCO, SERV50-DCX, which was designed for high-temperature application. The chemical composition, phase assembly, and some selected physical properties of the six refractory bricks are listed in Table 4.1.

A sodium-rich waste glass formulated for the Hanford Low Activity Waste vitrification project, LAWA24, was chosen for the comparative corrosion tests for the six refractory materials. LAWA24 was selected because this glass passed other major performance and processing tests and was considered as representative of the high sodium Hanford Low Activity Waste streams at the time this work was performed [9]; it should be noted however, that the Hanford LAW compositions have been refined since that time [see reference 6 and references therein]. The composition of LAWA24 is shown in Table 4.2.

\subsection{Chromium-Rich Oxide Refractory Bricks}

\subsubsection{K-3 ${ }^{\mathrm{TM}}$ from Carborundum}

Carborundum's $\mathrm{K}-3^{\mathrm{TM}}$ brick is a fused-cast chrome alumina refractory. It is made by casting a fusion of selected minerals and oxides from an electric arc furnace into graphite molds. The fusion solidifies into a solution of iron-chrome alumina crystals interspersed with a complex chrome-aluminous spinel (Figure 4.1). This unique combination of chemistry and fusion casting produces beneficial properties, such as low wetability and low penetrability. The low wetability and penetrability of $\mathrm{K}-3^{\mathrm{TM}}$ is reported to be largely responsible for its resistance to extremely fluid and corrosive slags and glasses [10]. The composition of $\mathrm{K}-3^{\mathrm{TM}}$ yields high-temperature load-bearing strength, thermal shock resistance and electrical resistivity, which are comparable with other fused-cast refractories [10]. The typical chemical composition and physical properties are listed in Table 4.1. 


\subsection{2 $E^{\mathrm{TM}}$ from Carborundum}

Carborundum's ETM brick is a fused-cast chrome-spinel refractory (Figure 4.2). It is made by casting a fusion of selected minerals and oxides from an electric arc furnace into graphite molds. The major crystalline phase (approximately 60\%) is a complex spinel $\left((\mathrm{Mg}, \mathrm{Fe}) \mathrm{O}-(\mathrm{Cr}, \mathrm{Al}, \mathrm{Fe})_{2} \mathrm{O}_{3}\right)$ that envelopes the secondary $\mathrm{R}_{2} \mathrm{O}_{3}$ phase (approximately 35\%) consisting of a solid solution of $\mathrm{Cr}, \mathrm{Fe}$, and $\mathrm{Al}_{2} \mathrm{O}_{3}$. The minor glassy matrix consists of less than $5 \%$ of the structure [11]. The typical chemical composition and physical properties are listed in Table 4.1. The electrical conductivity of $\mathrm{E}^{\mathrm{TM}}$ brick is 10 times higher than that of $\mathrm{K}-3^{\mathrm{TM}}$ because of the higher spinel content (Table 4.1).

\subsubsection{ER-2161 by Cohart}

ER-2161 is a fused cast refractory with alumina-zirconia-silica-chromia (Figure 4.3). The level of $\mathrm{Cr}_{2} \mathrm{O}_{3}$ is similar to that in $\mathrm{K}-3$, but with a much higher content of amorphous materials (20\%) and $\mathrm{ZrO}_{2}(27 \%)$ (Table 4.1). The refractory is recommended by the manufacturer for use in the heavy-wear area of the glass melter in dog-house corners, bubblers, and the throat [12]. The electric conductivity is similar to that of K-3 (Table 4.1).

\subsubsection{SERV50DCX ${ }^{\mathrm{TM}}$ from NARCO}

SERV50DCX ${ }^{\mathrm{TM}}$ is a bonded dense-cast chromia-alumina refractory from the North American Refractory Company (Figure 4.4). The bonded crystalline phase is roughly half- $\mathrm{Cr}_{2} \mathrm{O}_{3}$ and half- $\mathrm{Al}_{2} \mathrm{O}_{3}$ with minor other components (Table 4.1). In comparison to the fused-cast refractory, the porosity is significantly higher $(\sim 20 \mathrm{vol} . \%)$. The electric conductivity is similar to that of $\mathrm{K}-3^{\mathrm{TM}}$. The corrosion test conducted by the manufacturer at $1482^{\circ} \mathrm{C}$ in wool glass showed that SERV50DCX ${ }^{\mathrm{TM}}$ performed better than $\mathrm{K}-3^{\mathrm{TM}}$ in a 96 -hour glass contact test [13].

\subsubsection{CR60WB ${ }^{\mathrm{TM}}$ from VGT-Dyko}

CR60WB ${ }^{\mathrm{TM}}$ is a bonded chromia-alumina refractory manufactured using the hydrostatical pressing technique by VGT-DYKO Industriekeramik Vertriebs GmbH (Figure 4.5). The chromia content in CR60WB ${ }^{\mathrm{TM}}$ is higher than SERV50DCX ${ }^{\mathrm{TM}}$ (Table 4.1). CR60WB ${ }^{\text {TM }}$ is a relatively dense bonded refractory and has been used for lining Eglass tanks and rock wool furnaces [14]. 


\subsubsection{CR80AA ${ }^{\mathrm{TM}}$ from VGT-Dyko}

CR80AA $^{\mathrm{TM}}$ is a bonded chromia-alumina refractory manufactured using a machine-pressing technique from VGT-DYKO Industriekeramik Vertriebs $\mathrm{GmbH}$ (Figure 4.6). The chromia content in CR80AA ${ }^{\mathrm{TM}}$ is among the highest in the six refractories tested in this study. It has been used for patch plates for soda lime glass, in melting tanks for E-glass, glass wool, and mineral wool; and vitrification plants for filter dust and ash [15]. CR80AA ${ }^{\mathrm{TM}}$ and $\mathrm{E}^{\mathrm{TM}}$ have a similar chrome content yet a very different phase assembly and texture (Table 4.1)

\subsection{Results of Glass Contact Corrosion and Discussion}

The six oxide refractory bricks selected in this study are examples of good performers in the glass-contact corrosion tests conducted for different glasses at different test conditions. As shown in Table 4.1, they cover a wide range of chemical and physical properties:

- $\mathrm{Cr}_{2} \mathrm{O}_{3}$ content from $27 \mathrm{wt} \%$ to $80 \mathrm{wt} \%$;

- $\mathrm{Al}_{2} \mathrm{O}_{3}$ from $7 \%$ to $58 \%$;

- $\mathrm{ZrO}_{2}$ from 0 to $27 \mathrm{wt} \%$;

- $\mathrm{SiO}_{2}$ from trace to $15 \%$;

- Apparent porosity from 4 to $21 \%$;

- Spinel content from zero to $60 \%$;

- Solid-solution phase from 35 to nearly $100 \%$;

- Vitreous silicate matrix from a few percent to $20 \%$.

In addition, these materials allowed a direct comparison to be made between the corrosion rates of the fused-cast refractories and the bonded cast-pressed refractories.

Table 4.2 lists the dimension loss measurements for six refractory coupons after the standard six-day glass contact corrosion tests. No meaningful dimension loss measurement could be made for all three bonded refractory coupons because the parts of the refractory materials in contact with the molten glass had become so loose and separated that the test coupons had actually expanded beyond their original boundaries (Figures $4.7 \mathrm{a}$ and $\mathrm{b}$ ). The partially detached refractory fragments were cut through by the infiltrated glass melt, resulting in a sponge-like texture (Figures $4.8 \mathrm{a}, \mathrm{b}, \mathrm{c}$ ). It is likely that the glass would continue to penetrate deeper into the refractory bricks since no visible sign of any type of protective shield was visible under an Olympus optical microscope. In 
contrast, a much denser surface structure developed on the fused-cast refractories. Both K-3 ${ }^{\mathrm{TM}}$ and ER-2161 ${ }^{\mathrm{TM}}$ displayed an altered zone of around 15 to 19 mil thick within which grows a Cr-rich spinel phase (Figure 4-9a, b). The $\mathrm{Cr}$-Al solid-solution phase, the dominant crystalline phase in the pristine refractories, had disappeared completely after the six-day glass corrosion. No signs of alteration were observed for high-spinel ETM brick (Figure 4.10, Table 4.3). The dimension loss is rather limited for all three fused-cast bricks, a few mil at half down and from 15 to 28 mil at the necks (Table 4.3). E performed the best among the three refractories. K-3 ${ }^{\mathrm{TM}}$ and ER-2161 $1 \mathrm{TM}$ are comparable in many aspects in spite of the differences in composition and phase makeup. However, the altered $\mathrm{K}-3^{\mathrm{TM}}$ refractory is denser than the altered ER-2161 ${ }^{\mathrm{TM}}$ (Figures $4.11 \mathrm{a}, \mathrm{b}$ ). The voids near the surface of the ER-2161 ${ }^{\mathrm{TM}}$ are probably caused by the dissolution of $\mathrm{ZrO}_{2}$ crystals. The optical examination of the reacted coupons indicates that the denser fusedcast refractories are more resistant to glass corrosion than the more porous bonded castpressed refractory at $1208^{\circ} \mathrm{C}$, especially with regard to the structural damage caused by the penetration of the molten glass.

The dimension loss and the apparent density of the altered refractory surface measure the damage from the viewpoint of the corrosion as a physical process. Viewed as a chemical process, the refractory corrosion is the result of multi-phase heterogeneous chemical reactions. The molten glass, as part of the reactant as well as the reaction products at different stages of the corrosion process, evolves with the progress of the reaction. The glass compositions before and after corrosion tests show the material exchanges between the test coupons and the glass solvents. The concentration changes in the glasses with time, in particular, the concentration increases of the refractory-specific oxides, e.g., $\mathrm{Cr}_{2} \mathrm{O}_{3}$ and $\mathrm{Al}_{2} \mathrm{O}_{3}$, reflect the nature and level of the corrosion damage to the refractory coupons. Under the controlled surface-to-volume ratio, temperature, and agitating condition, the concentration changes of the reacted glasses can be used, on a relative basis, to compare the corrosion damages of different refractories, to infer the dominant reactions and controlling factors, and to monitor the corrosion progress (Figure 4.12 for schematics of the physical and chemical process). This method is especially suited for this study since half of the test coupons could not be measured meaningfully for dimension loss.

The concentration changes of the two most important refractory components, $\mathrm{Cr}_{2} \mathrm{O}_{3}$ and $\mathrm{Al}_{2} \mathrm{O}_{3}$, were used to evaluate the corrosion damages of the six chromia-rich refractories by LAWA24 glass. Assuming that the concentration increase of chromia in the glass indexes the degree of the dissolution or dimension loss of the refractory, the correlation analysis between the attributes of the refractory bricks and the chromia concentration change in the glass would indicate, the role of a particular attribute for the glass corrosion. Consequently, it is noteworthy that no clear relationship can be discerned between the chromia increases in the glass and the chromia contents in the refractory. For example, the refractories with similar $\mathrm{Cr}_{2} \mathrm{O}_{3}$ contents (e.g., ETM and CR80AA ${ }^{\mathrm{TM}}$ ) displayed very different chromia changes within the glasses (Table 4.2), and, as described earlier, have shown drastic differences in their dimension and structural changes as well (Table 4.3, Figures 4.8c, and Figure 4.10). Apparently, the brick chromia content alone does not determine the corrosion rates of a refractory coupon at $1208^{\circ} \mathrm{C}$. It was 
determined, however, that the chromia content of a refractory after excluding the amount bound in the spinel phase correlates linearly with the changes of chromia in the glass. In Figure 4.13, the $\mathrm{Cr}_{2} \mathrm{O}_{3}$ dissolved into the glass (in wt $\%$ ) increases approximately linearly with the $\mathrm{Cr}_{2} \mathrm{O}_{3}$ content in the non-spinel phase of a refractory (i.e., calculated as the difference of the $\mathrm{Cr}_{2} \mathrm{O}_{3}$ in the bulk refractory and the $\mathrm{Cr}_{2} \mathrm{O}_{3}$ in the spinel phase of the same refractory). The straight line in Figure 4.5 extrapolates to around $0.35 \mathrm{wt} \%$ of $\mathrm{Cr}_{2} \mathrm{O}_{3}$ in the LAWA24 glass as the non-spinel $\mathrm{Cr}_{2} \mathrm{O}_{3}$ in the refractory approaches zero. It is probably not coincidental that the starting glass, LAWA24, in fact, contains $0.33 \mathrm{wt} \%$ of $\mathrm{Cr}_{2} \mathrm{O}_{3}$. This simple linear relationship indicates clearly that the corrosion of the $\mathrm{Cr}$-rich refractory depends heavily on the phase assembly of the refractory materials and that the Cr-bearing complex spinel (termed spinel in the remainder of the report) as compared to the solid-solution phase of corundum-eskolaite (termed solid-solution phase) is much less susceptible to the glass attack. It is probably reasonable to suggest, therefore, that a higher-spinel refractory will be more corrosion resistant than a refractory of lower spinel content, everything else being similar. As shown in Figure 4.13, the data points for the K$3^{\mathrm{TM}}$ and especially $\mathrm{E}^{\mathrm{TM}}$ would lie far off the trend if the $\mathrm{Cr}_{2} \mathrm{O}_{3}$ of the bulk refractories were to be considered. It appears, therefore, that the $\mathrm{Cr}_{2} \mathrm{O}_{3}$ in the spinel phase does not contribute significantly to the $\mathrm{Cr}_{2} \mathrm{O}_{3}$ dissolved into the glass. In other words, it is primarily the solid-solution phase that dissolves. This inference is consistent with the microscopic examination by SEM/EDS that after the six-day air-bubbled test, the Crspinel phase is the only crystalline phase in the altered refractory near the surface of the test coupons; all solid-solution phases have either dissolved or transformed into the spinel phase (Figure 4.12). This concentration proportionality of glass versus refractory holds not only for $\mathrm{Cr}_{2} \mathrm{O}_{3}$ but also for $\mathrm{Al}_{2} \mathrm{O}_{3}$. Using the $\mathrm{K}-3^{\mathrm{TM}}$ test as our reference, the nonspinel $\mathrm{Cr}_{2} \mathrm{O}_{3}$ in the refractory and $\mathrm{Cr}_{2} \mathrm{O}_{3}$ change in glass have been normalized by the corresponding values for the $\mathrm{K}-3^{\mathrm{TM}}$ test, respectively. The results of the normalized releases of $\mathrm{Cr}_{2} \mathrm{O}_{3}$ (or $\mathrm{Al}_{2} \mathrm{O}_{3}$ ) into the glasses are plotted versus the normalized non-spinel $\mathrm{Cr}_{2} \mathrm{O}_{3}$ (or $\mathrm{Al}_{2} \mathrm{O}_{3}$ ) content in the refractory materials. Both oxides show linear trends of slope equal to the one shown in Figures 4.14 and 4.15. This simply means that more $\mathrm{Cr}_{2} \mathrm{O}_{3}$ will be released from the refractory to the molten glass as the $\mathrm{Cr}_{2} \mathrm{O}_{3}$ exposed in the solid-solution phase increases. The higher $\mathrm{Cr}_{2} \mathrm{O}_{3}$ content in the refractory, if not present as the spinel, does not appear to contribute to improved corrosion resistance. The one-toone ratio clearly defined in Figures 4.14 and 4.15 again supports the argument that the solid-solution phase is much more unstable (either kinetically or thermodynamically) than the spinel phase in the presence of the high-sodium waste glass at $1208^{\circ} \mathrm{C}$. A high spinel content, rather than the high $\mathrm{Cr}_{2} \mathrm{O}_{3}$ content, is therefore preferred in the selection of an oxide based refractory for lining high-alkali waste glass melters. On the other hand, the content of the spinel in the refractory brick is limited by the allowable electrical conductivity of the brick since high conductivities ultimately provide a shorting path around the melt in Joule-heated melters. The electrical conductivity of the crystalline spinel phase in fused-cast brick is an order of magnitude higher than that of the solidsolution phase. In spite of the excellent corrosion resistance, the $\mathrm{E}^{\mathrm{TM}}$ brick, the highest spinel refractory of the six, is not suitable for lining substantial portions of the glasscontact part of the melter because of its high electrical conductivity, which is similar to that of a typical nuclear waste molten glass (Table 4.1). Overall, therefore, K-3 ${ }^{\mathrm{TM}}$ proves to be a good choice in view of its order of magnitude lower electrical conductivity than 
the typical waste glasses (Table 4.1) and rather high resistance to glass attack. ER-2161 TM provides a non-spinel alternative with similar corrosion resistance but with rather high $\mathrm{ZrO}_{2}$ content. Microscopic examination of the corroded ER-2161 ${ }^{\mathrm{TM}}$ coupons indicated a significant amount of voids near the surface of the refractory that is probably caused by dissolution of $\mathrm{ZrO}_{2}$ in the brick (Figures $4.9 \mathrm{~b}$ and 4.11). Additional control would be needed to curb the dissolution of the $\mathrm{ZrO}_{2}$ phase. The three bonded refractory bricks performed poorly in every aspect of the corrosion tests. The high $\mathrm{Cr}_{2} \mathrm{O}_{3}$ contents in the bricks do not serve to reduce the damage by glass attack. The high level of the porosity further facilitates the penetration of the molten glass, resulting in extensive disintegration inside the refractory brick. None of the three is recommended for application as the glass contact part in the Joule-heated waste glass melters.

\subsection{Conclusions}

Six Cr-rich oxide refractory bricks have been tested for their corrosion resistance to a representative sodium-rich low activity waste glass. The refractory bricks were selected to cover wide ranges of chrome content, phase assembly, grain structure and fabrication method. The comparative analysis of the reacted refractory coupons and glasses has led to the following conclusions.

1) The denser fused-cast refractories in general are more resistant to the penetration of the molten glass at $1208^{\circ} \mathrm{C}$. The altered parts of the three fused-cast refractories remained structurally connected to the refractory bodies after the six-day corrosion tests. The apparent surface density is relatively high. In contrast, the more porous pressed-cast bonded refractories are relatively more easily penetrated by the alkalirich molten glass. The refractory bricks near the surface lost their structural integrity after the six-day corrosion tests, and became physically separated and fragmented by the infiltrating glass melts.

2) The dissolution of the Cr-rich oxide refractories by the molten glass is, to a large extent, determined by the phase assemblies of the refractory bricks, more specifically, by the ratio of the spinel phase to the solid-solution phase. The dissolution of the solid-solution phase contributes the majority of the concentration increases of $\mathrm{Cr}_{2} \mathrm{O}_{3}$ and $\mathrm{Al}_{2} \mathrm{O}_{3}$ in the reacted glass. After six days of dynamic glass contact corrosion, the solid-solution phase has been completely dissolved or transformed near the surface of the test refractories. It is evident that the glass contact corrosion rate will be affected more by the spinel content than by the $\mathrm{Cr}_{2} \mathrm{O}_{3}$ concentration of an oxide refractory. A reasonably higher $\mathrm{Cr}$-rich spinel content is recommended for an oxide refractory for application in Joule-heated ceramic melters.

3) $\mathrm{K}-3^{\mathrm{TM}}$ is recommended as the best choice for application in Joule-heated ceramic melters. If the melter design is such that the electrical conductivity is not a concern, then $\mathrm{E}^{\mathrm{TM}}$ may be a better choice. The dimension loss and the material dissolution of $\mathrm{K}-3^{\mathrm{TM}}$ are reasonably low in the group of the refractories tested in this study. The 
outstanding corrosion resistance and acceptable electrical conductivity of $\mathrm{K}-3^{\mathrm{TM}}$ is ascribed to its moderate spinel content and dense fused-cast grain structure.

4) A simple one-to-one ratio between the two pairs of the normalized oxides in the refractory and in the glass has been identified. Although this simple relationship indicates clearly the involvement of the solid-solution phase in the early stage dissolution of the refractory materials to the molten glass, it is not clear what causes such a linear trend. Corrosion tests different time intervals would be helpful in addressing this question. 


\section{SECTION 5.0 \\ CONTROLLING FACTORS FOR K-3 CORROSION IN HIGH-SODIUM WASTE GLASS MELTS}

\subsection{Introduction}

As is the case for commercial glass melters, the rate of corrosion of the glasscontact material that lines the melter is a major factor in determining the lifetime and maintenance requirements for waste glass melters. However, the complexity and variability of typical waste glass compositions coupled with the increased difficulty of repair or replacement in radioactive or hazardous environments make this a particularly important issue. Some of the more important factors affecting the rate of refractory corrosion include the type, structure and compositions of refractory materials, which has been described in the Section 4 of this report, the melter operating temperature, and the glass composition. Comparative tests of potential refractory materials for use in the US high-level nuclear waste vitrification program (see, e.g., reference [16] and references therein) have led to the selection of Monofrax $\mathrm{K}-3^{\mathrm{TM}}$ as the material of choice; in fact, that material was used in all three of the full-scale radioactive waste melters that have operated in the US (WVDP at West Valley, NY; DWPF and the Duratek M-Area VTF, both at the Savannah River site, SC). Earlier studies, including the comparative corrosion tests of six high $\mathrm{Cr}$ oxide refractory bricks reported earlier in this document, have identified $\mathrm{K}-3^{\mathrm{TM}}$ as one of the overall best performing refractories for the glass contact application of diverse waste streams [2-5]. Despite the continued use of K-3 ${ }^{\mathrm{TM}}$, there have been relatively few studies on the mechanisms by which K-3 $3^{\mathrm{TM}}$ is attacked by waste glasses. Moreover, $\mathrm{K}-3^{\mathrm{TM}}$ in contact with different glasses still displays a wide range of corrosion rates, from very corrosion resistant to extensive corrosion, as the test conditions and waste glass compositions are varied. Improved understanding of the underlying corrosion mechanisms that give rise to these effects is important in the selection of appropriate refractory materials as well as in the design of waste glass compositions and improved refractories.

In the second part of this report, we focus on high-sodium waste glass compositions of the general type that were employed for mixed wastes vitrified at the MArea at the Savannah River site, or might be appropriate for tank wastes at the Hanford (LAW) or Idaho sites. The basic issue that we address is the relative importance of kinetic factors (e.g., material transport) and thermodynamic factors (e.g., solubility) in controlling the corrosion rate. This will be done by examining the variations in the time dependence of the composition of the reaction products, both on the refractory and in the melt, with temperature, melt viscosity, and the surface area of refractory available to a given volume of melt. 


\subsection{General Approach}

Monofrax $\mathrm{K}-3^{\mathrm{TM}}$ is a fused-cast $\mathrm{Cr}$-rich oxide refractory consisting primarily of an eskolaite-corundum solid-solution phase and a $\mathrm{Mg}-\mathrm{Cr}-\mathrm{Al}-\mathrm{Fe}$ complex-spinel phase. The compositions of the two crystalline phases change in response to changes in temperature and changes in the compositions of other phases with which they coexist, either that of the melt or other solid phases that may be present in the system. Thus, the refractory corrosion process involves continuous composition changes in both the crystalline phases near the surface of the refractory and the coexisting melt. As a consequence of the much faster rate of mass transport in the liquid phase than in the solid phases over typical experimental time scales, liquid-crystal equilibrium can only be obtained locally (if at all) between the homogeneous liquid and the surface crystalline phase assemblage. Therefore, the path of approach of the system towards its equilibrium state can be tracked by monitoring the compositional evolution of the materials near the phase boundary. Furthermore, if kinetic factors (rather than the thermodynamic reaction affinity) are responsible for controlling the rate of corrosion, the extent of the heterogeneous reactions at a given time will vary with the number of reaction sites available, which can be adjusted by varying the refractory surface area for a given melt volume. Thus, from a practical point of view, by increasing the surface to volume ratio $(\mathrm{S} / \mathrm{V})$ under otherwise identical conditions, the refractory-melt reactions can be accelerated in order to approach the equilibrium state in a manageable experimental time.

These principles were employed in the present study. The compositions of crystalline phases near the surface of the reacted $\mathrm{K}-3^{\mathrm{TM}}$ refractory were determined by SEM-EDX techniques in corrosion tests that were conducted with both monolithic K-3 ${ }^{\mathrm{TM}}$ (low S/V) and with powdered K-3 ${ }^{\mathrm{TM}}$ (high S/V). Finally, in separate tests, the melt was exposed to an excess of one of the constituents of $\mathrm{K}-3^{\mathrm{TM}}\left(\mathrm{Cr}_{2} \mathrm{O}_{3}\right)$ in the absence of $\mathrm{K}-3^{\mathrm{TM}}$ in order to investigate whether a similar final state is approached.

Two sodium-rich alumino-borosilicate glasses were used in this study. The glasses were formulated to have similar major components but different viscosities by increasing the boron content at the expense of all other components except alkalies. Thus, the glasses had nominally equal mole percents of $\mathrm{Na}_{2} \mathrm{O}, \mathrm{Li}_{2} \mathrm{O}$ and $\mathrm{K}_{2} \mathrm{O}$ since these are known to have strong effects on the rate of corrosion; the analyzed compositions (by dissolution followed by solution analysis by Direct Current Plasma-Emission Spectroscopy (DCP-ES)) of the glasses are shown in Table 5.1. The viscosity of the highboron glass is approximately $60 \%$ lower than that of the base. Both glasses were made by quenching melts that were equilibrated in air at $1200^{\circ} \mathrm{C}$. 


\subsection{Results and Discussion}

The monolithic K-3 coupons suffered considerable dimensional loss and alteration near the surface of the coupon after the six-day corrosion tests (Table 5.2). The altered zone, the depth of which varied with the temperature and glass composition, is characterized by a single fine-grained spinel phase with a much higher $\mathrm{Cr} / \mathrm{Al}$ ratio than that in the virgin $\mathrm{K}-3^{\mathrm{TM}}$. The $\mathrm{Cr}-\mathrm{Al}$ solid-solution phase has disappeared entirely in the altered zone as a result of the glass-refractory reactions. As Figure 5.1 shows for the case of the base glass, the chromium content of the corresponding glass phase changed rapidly in the first two days before leveling off to a more or less constant value. This behavior could be due to the approach to a state that is either thermodynamically stable (i.e., representing "saturation" of the reacted melts) or one that is kinetically hindered with respect to further change (e.g., as a result of the formation of a more slowly-dissolving alteration product). The results of other tests, discussed below, shed light on the relative importance of these two effects.

Figures 5.2 and 5.3 show the time evolutions of the chromium and aluminum contents, respectively, of the interface spinel (spinel in the altered layer) as the granular $\mathrm{K}-3^{\mathrm{TM}}$ material reacts with and dissolves into the two glass melts. Also shown in those figures is the composition of the interface spinel that is formed in the tests with monolithic $\mathrm{K}-3^{\mathrm{TM}}$ and the time evolution of the composition of the spinel phase that is formed from the glass melts in tests without $\mathrm{K}-3^{\mathrm{TM}}$ but with an excess of $\mathrm{Cr}_{2} \mathrm{O}_{3}$. The data are suggestive of a convergence towards a common spinel phase composition (of roughly 25 atom $\% \mathrm{Cr}$ and 5 atom $\% \mathrm{Al}$ ) in all of these tests. This indicates that the plateau in the chromium content of the melt shown in Figure 5.1 is a consequence of the approach to the saturation of the melt with respect to that common spinel phase composition. Since chromium release into the glass is one measure of the extent of corrosion, these results imply that the corrosion rate declines with time as a result of the approach to saturation. While this does appear to be the case under the conditions of the present study, it is important to emphasize that, more generally, we have found that chromium release into the glass may or may not be a reliable indication of the practical extent of corrosion since both the morphology and phase assemblage of the altered layer can play important roles in the overall corrosion process.

Finally, we turn to the effects of temperature and melt viscosity on the corrosion process. It is clear from Figures 5.2 and 5.3 that the interface spinel coexisting with the lower-viscosity melt attained the presumed equilibrium composition considerably faster than that coexisting with the base melt. This suggests that the rates of dissolution and transformation of the $\mathrm{Cr}-\mathrm{Al}$ spinel depend strongly on the rate of material transport in the melts and that the spinel (and probably also the solid-solution phase) dissolves faster in less viscous melts at the same temperature. The results from the reaction of granular K$3^{\mathrm{TM}}$ with the base glass at $1208^{\circ} \mathrm{C}$ and $1283 \mathrm{EC}$ show that the rates of dissolution and transformation of the $\mathrm{Cr}-\mathrm{Al}$ spinel are greater at higher temperatures (Figures 5.4 and $5.5)$. 
The evolution of the spinel and melt phase compositions with time can be rendered in terms of the "Normalized Variation (N.V.)," which we define as:

$$
\mathrm{N} . \mathrm{V}=\frac{\mathrm{Cr}_{2} \mathrm{O}_{3} \text { (wt\% increase in glass) } / \mathrm{Cr}_{2} \mathrm{O}_{3} \text { (wt\% in interface spinel) }}{\mathrm{Al}_{2} \mathrm{O}_{3} \text { (wt \% increase in glass) } / \mathrm{Al}_{2} \mathrm{O}_{3} \text { (wt\% in interface spinel) }}
$$

This parameter compares the amount of $\mathrm{Cr}_{2} \mathrm{O}_{3}$ released into the glass relative to its concentration in the presumed surface phase that is reacting (the interface spinel) to the same ratio for $\mathrm{Al}_{2} \mathrm{O}_{3}$. Thus, congruent dissolution of the reacting surface phase would correspond to a value of unity, whereas a value of less than unity implies selective dissolution of that phase favoring $\mathrm{Al}_{2} \mathrm{O}_{3}$. At each time step, analysis of a sample of the reacted glass gave the increases in $\mathrm{Cr}_{2} \mathrm{O}_{3}$ and $\mathrm{Al}_{2} \mathrm{O}_{3}$ while SEM-EDS analysis of the reacted $\mathrm{K}-3^{\mathrm{TM}}$ surface gave the composition of the interface spinel, which together permitted calculation of the N.V. Figure 5.6 shows the time dependence of the normalized variations calculated in this way from the measured compositions of the spinel and melt phases. The results show that the $\mathrm{K}-3^{\mathrm{TM}}$ dissolution process favors $\mathrm{Al}_{2} \mathrm{O}_{3}$ over $\mathrm{Cr}_{2} \mathrm{O}_{3}$ and is fastest in the base glass at $1283 \mathrm{EC}$, followed by the low-viscosity glass at $1208 \mathrm{EC}$, and slowest in the base glass at 1208EC (see Figure 5.6). The value of N.V. falls quickly to near zero after about 3 days reflecting the "saturation" behavior shown in Figure 5.1. (Note that while negative values of N.V. (corresponding to precipitation from the glass to the $\mathrm{K}-3^{\mathrm{TM}}$ ) are possible and, indeed observed for some components, the values in Figure 5.6 at long periods are zero to within the experimental uncertainty). Although it is not possible to separate the effects of temperature and viscosity on the reactions on the basis of the data reported (such results will be reported elsewhere), it is nevertheless evident that both parameters have significant effects on the dissolution rate of $\mathrm{K}-3^{\mathrm{TM}}$.

\subsection{Conclusions}

The corrosion of Monofrax K-3 the two major crystalline phases of which it is composed. In the sodium-rich waste glass melts investigated, there was considerable loss due to corrosion after six days at temperatures of 1200EC and above. An altered zone, composed of a fine-grained modified Cr-rich spinel but none of the original eskolaite-corundum solid-solution phase, developed at the surface of the reacted refractory, implying that the Cr-rich spinel phase was thermodynamically more stable than the solid-solution phase for the melts and conditions tested. The compositions of the Cr-rich spinel phase and the melts evolved with time and came close to mutual equilibrium within six days, which resulted in a decreasing rate of reaction over that time. The results also showed that the rate of dissolution and transformation of the spinel phase depended strongly on the temperature and the melt viscosity. 


\section{SECTION 6.0 K-3 GLASS CONTACT CORROSION OF SELECTED GLASSES}

The refractory corrosion results presented in the Sections 4.0 and 5.0 of this report illustrate the roles of the refractory and glass in the Cr-rich oxide refractory corrosion process. The conclusions derived from these studies are applicable to the selection of the refractory materials and for glass formulation development. However, K-3 corrosion as an application problem encountered in the design and construction of Joule-heated ceramic melter requires more specific data on magnitudes of corrosion rates to be expected in actual service, as compared to the comparative data discussed earlier. For this purpose, it is important to be able to relate the results from the small-scale coupon tests to results from full-scale operations. This Section presents corrosion data for K-3 refractory in three representative glass melts, including one with a known track record of refractory corrosion rate in a full scale melter, such as is available for the West Valley Reference glass.

\subsection{K-3 Corrosion in Hanford High-Level Waste Glass at 1208,1283 and $1389^{\circ} \mathrm{C}$}

Three HLW glasses were selected to test the temperature dependence of $\mathrm{K}-3^{\mathrm{TM}}$ corrosion rates based on earlier glass formulation work [17]. The three glasses were formulated with similar concentrations of alkalis, alumina, chromia, iron oxide, but progressively reduced $\mathrm{B}_{2} \mathrm{O}_{3}$ to compensate for the changes of the melt viscosity as caused by the temperature increases. The glass compositions before and after the corrosion tests are listed in Table 6.1 and the dimension loss data are summarized in Table 6.2. Figures $6.1 \mathrm{a}, \mathrm{b}$, and $\mathrm{c}$ show the optical images of the test $\mathrm{K}-3^{\mathrm{TM}}$ coupons after the six-day corrosion tests at 1208,1283 and $1389^{\circ} \mathrm{C}$ respectively.

\subsection{K-3 ${ }^{\mathrm{TM}}$ Corrosion of Two Reference glasses (WVDP and SRL-EA)}

The K-3 $3^{\text {TM }}$ corrosion of two reference glasses, WVREF6, which was produced at West Valley ("Reference 6") and SRL-EA (the DWPF EA glass), are reported in this Section. The coupon test results reported here provide important reference points for assessing the small-scale corrosion data. The glass compositions before and after corrosion are listed in Table 6.3, and the coupon dimension loss data are listed in Table 6.4. Figure $6.2 \mathrm{a}$, and $\mathrm{b}$ show the optical images of the test $\mathrm{K}-3$ coupons after the six-day corrosion tests in WVREF6 and SRL-EA glass, respectively. 


\section{SECTION 7.0 REFERENCES}

[1] H. Gan and I.L. Pegg, "K-3 Refractory Corrosion and Glass Formulation Development for the GTS Duratek M-Area Mixed Waste Vitrification Facility," Unpublished work, 1997.

[2] S.B. Xing, Y. Lin, R.K. Mohr, and I.L. Pegg, "Corrosion Resistance of Ceramic Refractories to Simulated Waste Glasses at High Temperatures," Scientific Basis for Nuclear Waste Management XIX, Eds. W.M. Murphy and D.A. Knecht, MRS, Pittsburgh, PA, 412, 181 (1996).

[3] E. Wang, R.K. Mohr, A.C. Buechele, and I.L. Pegg, "Current Density Effects on the Corrosion of Ceramic and Metallic Electrode Materials in Waste Glasses," Scientific Basis for Nuclear Waste Management XIX, Eds. W.M. Murphy and D.A. Knecht, MRS, Pittsburgh, PA, 412181 (1996).

[4] A.C. Buechele, S.S. Fu, Q. Yan, and I.L. Pegg, "Radionuclide Uptake by Waste Glass Melter Refractories," Environmental Issues and Waste Management Technologies in the Ceramic and Nuclear Industries III, Eds. D.K. Peeler and J.C. Marra, Ceramic Transactions, 87, p. 583 (1998).

[5] I.S. Muller, A.C. Buechele, F. Perez-Cardenas, H. Gan, and I.L. Pegg, "Partitioning of Plutonium Between Glass, Secondary Phases, and Contract Refractories," Mat. Res. Soc. Symp. Proc, 556 p. 271 (1999).

[6] Hao Gan, X.D. Lu, Igor Vidensky, Catherine Paul and Ian L. Pegg, "Corrosion of K-3 Refractory and Metal Alloys in RPP-WTP LAW Glasses', Final Report, VSL-01R3540-1, March 16, 2001.

[7] Hao Gan, X.D. Lu, Igor Vidensky, Catherine Paul and Ian L. Pegg, "Corrosion of K-3 Refractory and Metal Alloys in RPP-WTP HLW Glasses', Final Report, VSL-01R2550-1, March 12, 2001.

[8] Standard Test Method for Isothermal Corrosion Resistance of Refractories to Molten Glass, ASTM Designation C621-84.

[9] I.S. Muller and I.L. Pegg, "Glass Formulation and Testing With TWRS LAW Simulants", Final Report, VSL of Catholic University of America, January 16, 1998.

[10] Type K-3 Fused Cast Refractory Product Information, Form A-2850, Carborundum Company, 1991. 
[11] Type E Fused Cast Refractory Product Information, Form A-2848, Carborundum Company, 1990.

[12] Technical information on ER 2161, SEPR Product Catalogue, 1996.

[13] Preliminary Plant Test Data of SERV50DCX by North American Refractories Co., 1996.

[14] Technical data for CR60WB from Preliminary Data Sheet of VGT-DYCO.

[15] Technical data for CR80AA from Preliminary Data Sheet of VGT-DYCO.

[16] D.F. Bickford, R.S. Ondrejcin, L. Salley, "High-Temperature Materials for Radioactive Waste Incineration and Vitrification," Advances in Ceramics, Nuclear Waste Management II 20 p. 65 (1986).

[17] "Glass Formulation and Testing with TWRS HLW Simulants," S.S. Fu and I.L. Pegg, VSL Final Report, January 1998. 
Table 4.1. Phase Assembly, Bulk Composition, and Some Physical Properties of the Selected Oxide Refractory Materials.

\begin{tabular}{|c|c|c|c|c|c|c|}
\hline Composition/Property & $\begin{array}{c}\text { Carborundum } \\
\text { E }^{\mathrm{TM}}\end{array}$ & $\begin{array}{c}\text { Carborundum } \\
\mathrm{K}-3^{\mathrm{TM}}\end{array}$ & $\begin{array}{l}\text { Corhart } \\
\text { ER2161 }\end{array}$ & $\begin{array}{c}\text { NARCO } \\
\text { Serv50DCX }\end{array}$ & $\begin{array}{l}\text { VGT-Dyko } \\
\text { CR60WB }\end{array}$ & $\begin{array}{c}\text { VGT-Dyko } \\
\text { CR80AA }\end{array}$ \\
\hline Major Phase I & $\begin{array}{l}\mathrm{Cr}_{2} \mathrm{O}_{3}-\mathrm{Al}_{2} \mathrm{O}_{3} \\
\text { complex spinel } \\
60 \%\end{array}$ & $\begin{array}{l}\mathrm{Cr}_{2} \mathrm{O}_{3}-\mathrm{Al}_{2} \mathrm{O}_{3} \\
\text { solid solution } \\
60 \%-65 \%\end{array}$ & $\begin{array}{l}\mathrm{Al}_{2} \mathrm{O}_{3}-\mathrm{Cr}_{2} \mathrm{O}_{3} \\
\text { solid solution } \\
53 \%\end{array}$ & $\begin{array}{l}\mathrm{Cr}_{2} \mathrm{O}_{3}-\mathrm{Al}_{2} \mathrm{O}_{3} \\
\text { solid solution }\end{array}$ & $\begin{array}{l}\mathrm{Cr}_{2} \mathrm{O}_{3}-\mathrm{Al}_{2} \mathrm{O}_{3} \\
\text { solid solution }\end{array}$ & $\begin{array}{l}\mathrm{Cr}_{2} \mathrm{O}_{3}-\mathrm{Al}_{2} \mathrm{O}_{3} \\
\text { Solid solutions }\end{array}$ \\
\hline Major Phase II & $\begin{array}{l}\mathrm{Cr}_{2} \mathrm{O}_{3}-\mathrm{Al}_{2} \mathrm{O}_{3} \text { solid } \\
\text { solution } 35 \%\end{array}$ & $\begin{array}{l}\text { Complex spinel } \\
35 \%-40 \%\end{array}$ & Zirconia $27 \%$ & - & - & - \\
\hline $\mathrm{Al}_{2} \mathrm{O}_{3}$ & 6.5 & 58.6 & 28 & 47.9 & 30 & 10 \\
\hline $\mathrm{Cr}_{2} \mathrm{O}_{3}$ & 77.7 & 27.1 & 27 & 49.0 & 60 & 77 \\
\hline $\mathrm{Fe}_{2} \mathrm{O}_{3}$ & 5.9 & 5.9 & $\begin{array}{l}2.4 \text { (with } \\
\mathrm{MgO} \text { ) }\end{array}$ & 0.3 & - & $\overline{-}$ \\
\hline $\mathrm{MgO}$ & 7.4 & 6.1 & (with $\mathrm{Fe}_{2} \mathrm{O}_{3}$ ) & 1.0 & - & - \\
\hline $\mathrm{SiO}_{2}$ & 1.7 & 1.6 & 14.5 & 1.3 & - & 3 \\
\hline $\mathrm{TiO}_{2}$ & - & - & - & - & 4 & \\
\hline $\mathrm{ZrO}_{2}$ & - & - & 27 & - & 5 & 6 \\
\hline Porosity & $5 \mathrm{vol} \%$ & 4 vol\% & Not available & $20 \mathrm{vol} \%$ & $16 \mathrm{vol} \%$ & $21 \mathrm{vol} \%$ \\
\hline Electric Resistivity & $\begin{array}{l}10 \mathrm{ohm}-\mathrm{cm} \text { at } \\
1200^{\circ} \mathrm{C}\end{array}$ & $\begin{array}{l}\sim 200 \mathrm{ohm}-\mathrm{cm} \text { at } \\
1200^{\circ} \mathrm{C}\end{array}$ & $\begin{array}{l}\sim 100 \mathrm{ohm}-\mathrm{cm} \\
\text { at } 1200^{\circ} \mathrm{C}\end{array}$ & $\begin{array}{l}\sim 110 \mathrm{ohm}-\mathrm{cm} \text { at } \\
1200^{\circ} \mathrm{C}\end{array}$ & $\begin{array}{l}\sim 140 \text { ohm-cm at } \\
1200^{\circ} \mathrm{C}\end{array}$ & Not available \\
\hline Density $\left(\mathrm{g} / \mathrm{cm}^{3}\right)$ & 4.17 & 3.83 & 4.11 & 3.48 & 3.8 & 3.8 \\
\hline $\begin{array}{l}\text { None-spinel } \mathrm{Cr}_{2} \mathrm{O}_{3} \\
\text { wt } \%\end{array}$ & 25 & 18 & 27 & 49 & 60 & $\overline{77}$ \\
\hline
\end{tabular}


Table 4.2. LAWA24 Glass Compositions Before and After the Standard Coupon Corrosion Tests.

\begin{tabular}{|c|c|c|c|c|c|c|c|c|}
\hline Test Name & \multicolumn{2}{|c|}{ Starting Glass } & $\overline{\mathrm{E}}$ & K-3 & ER-2161 & SERV-50DCX & CR80-AA & CR60-WB \\
\hline Component & Target & DCP (wt $\%)$ & $\overline{D C P}(w t \%)$ & $\overline{\mathrm{DCP}}(\mathrm{wt} \%)$ & $\overline{\mathrm{DCP}}(\mathrm{wt} \%)$ & DCP $(w t \%)$ & $\mathrm{DCP}(w \mathrm{t} \%)$ & DCP (wt\%) \\
\hline & (wt\%) & Normalized & Normalized & Normalized & Normalized & Normalized & Normalized & Normalized \\
\hline $\mathrm{Al}_{2} \mathrm{O}_{3}$ & 12.37 & 12.11 & 13.14 & 14.08 & 13.43 & 14.10 & 12.88 & 13.71 \\
\hline$\overline{\mathrm{B}_{2} \mathrm{O}_{3}}$ & 6.11 & 7.04 & 5.22 & 5.28 & 5.41 & 5.14 & 5.30 & 5.33 \\
\hline $\mathrm{CaO}$ & 3.28 & 3.79 & 3.88 & 3.89 & 3.85 & 3.88 & 4.02 & 3.93 \\
\hline $\mathrm{CdO}$ & 0.33 & 0.37 & 0.26 & 0.26 & 0.27 & 0.24 & 0.27 & 0.26 \\
\hline $\mathrm{Cr}_{2} \mathrm{O}_{3}$ & 0.34 & 0.32 & 0.82 & 0.62 & 0.81 & 1.28 & 1.43 & 0.90 \\
\hline $\mathrm{Fe}_{2} \mathrm{O}_{3}$ & 6.01 & 6.01 & 6.4 & 6.59 & 6.35 & 6.42 & 6.56 & 6.42 \\
\hline $\mathrm{K}_{2} \mathrm{O}$ & 5.48 & 4.93 & 3.73 & 3.55 & 3.60 & 3.69 & 3.85 & 3.47 \\
\hline$\overline{\mathrm{MgO}}$ & 0.00 & 0.04 & 0.35 & 0.24 & 0.07 & 0.05 & 0.03 & 0.04 \\
\hline $\mathrm{Na}_{2} \mathrm{O}$ & 20.04 & 19.20 & 17.87 & 18.41 & 18.16 & 17.86 & 17.62 & 18.15 \\
\hline $\mathrm{NiO}$ & 0.14 & 0.15 & 0.16 & 0.13 & 0.14 & 0.14 & 0.14 & 0.13 \\
\hline$\overline{\mathrm{P}_{2} \mathrm{O}_{5}}$ & 1.74 & 1.86 & 2.02 & 1.84 & 1.97 & 1.95 & 1.92 & 1.96 \\
\hline $\mathrm{PbO}$ & 0.10 & 0.16 & 0.13 & 0.13 & 0.13 & 0.11 & 0.12 & 0.13 \\
\hline $\mathrm{SO}_{3}$ & 0.50 & 0.47 & 0.00 & NA & $\mathrm{NA}$ & 0.13 & 0.13 & NA \\
\hline $\mathrm{SiO}_{2}$ & 35.43 & 37.42 & 39.93 & 39.03 & 39.42 & 39.08 & 39.69 & 39.46 \\
\hline $\mathrm{TiO}_{2}$ & 0.00 & 0.06 & 0.03 & 0.02 & 0.02 & 0.02 & 0.15 & 0.08 \\
\hline $\mathrm{ZnO}$ & 3.05 & 3.21 & 3.23 & 3.08 & 3.02 & 2.98 & 2.69 & 2.98 \\
\hline $\mathrm{ZrO}_{2}$ & 3.05 & 2.71 & 2.68 & 2.70 & 3.22 & 2.83 & 3.13 & 2.91 \\
\hline $\mathrm{Cl}$ & 0.85 & NA & NA & NA & $\overline{\mathrm{NA}}$ & NA & NA & NA \\
\hline $\mathrm{F}$ & 1.12 & NA & NA & NA & NA & NA & NA & NA \\
\hline
\end{tabular}

NA - Not Analyzed 
Table 4.3. Characteristic Corrosion Damage for Six Oxide Refractory Coupons.

\begin{tabular}{|c|c|c|c|c|c|}
\hline & $\begin{array}{l}\text { Neck Loss } \\
\text { (inch) }\end{array}$ & $\begin{array}{l}\text { Half Dow Loss } \\
\text { (inch) }\end{array}$ & $\begin{array}{l}\text { Thickness of } \\
\text { Fully Altered } \\
\text { Zone (inch) }\end{array}$ & $\begin{array}{l}\text { Structure } \\
\text { Integrity }\end{array}$ & $\begin{array}{l}\text { Phase in the } \\
\text { Fully Altered } \\
\text { Zone after } \\
\text { Corrosion Test }\end{array}$ \\
\hline CR60WB & $\mathrm{N} / \mathrm{A}^{*}$ & $\mathrm{~N} / \mathrm{A}^{*}$ & $\mathrm{~N} / \mathrm{A}^{*}$ & $\begin{array}{l}\text { Very loose } \\
\text { structure }\end{array}$ & Spinel \\
\hline CR80AA & $\mathrm{N} / \mathrm{A}^{*}$ & N/A* & $\mathrm{N} / \mathrm{A}^{*}$ & $\begin{array}{l}\text { Very loose } \\
\text { structure }\end{array}$ & Spinel \\
\hline SERV50DCX & $\mathrm{N} / \mathrm{A}^{*}$ & N/A* & $\mathrm{N} / \mathrm{A}^{*}$ & $\begin{array}{l}\text { Very loose } \\
\text { structure }\end{array}$ & Spinel \\
\hline $\bar{E}$ & 0.01555 & 0.00140 & 0 & $\begin{array}{l}\text { Very dense } \\
\text { structure }\end{array}$ & Spinel \\
\hline ER2161 & 0.02730 & 0.00081 & 0.01896 & $\begin{array}{l}\text { Void near } \\
\text { surface }\end{array}$ & Spinel $+\mathrm{ZrO}_{2}$ \\
\hline $\mathrm{K}-3$ & 0.02600 & 0.00275 & 0.01510 & Dense structure & Spinel \\
\hline
\end{tabular}

*No meaningful dimension loss can be measured. See text for detail. 
Table 5.1. Analyzed Compositions of the Glasses Used in this Study.

$(\mathrm{Wt} \%)$

\begin{tabular}{|l|l|l|l|l|l|l|l|l|l|l|l|l|}
\hline & $\mathrm{Al}_{2} \mathrm{O}_{3}$ & $\mathrm{~B}_{2} \mathrm{O}_{3}$ & $\mathrm{Fe}_{2} \mathrm{O}_{3}$ & $\mathrm{~K}_{2} \mathrm{O}$ & $\mathrm{Li}_{2} \mathrm{O}$ & $\mathrm{MgO}$ & $\mathrm{Na}_{2} \mathrm{O}$ & $\mathrm{NiO}$ & $\mathrm{P}_{2} \mathrm{O}_{5}$ & $\mathrm{SiO}_{2}$ & Others \\
\hline Base glass & 12.41 & 14.69 & 0.98 & 1.84 & 2.55 & 1.98 & 17.21 & 0.43 & 3.93 & 40.09 & 3.89 \\
\hline $\begin{array}{l}\text { Low-viscosity } \\
\text { glass }\end{array}$ & 9.90 & 21.08 & 0.81 & 2.11 & 2.56 & 1.95 & 16.83 & 0.42 & 3.64 & 36.60 & 4.10 \\
\hline
\end{tabular}

Table 5.2. One-Sided Corrosion Loss and Thickness of Modified Layer on Corroded K-3 Coupons.

\begin{tabular}{|l|c|c|c|}
\hline & $\begin{array}{c}\text { Lost at half-down } \\
\text { (inch) }\end{array}$ & $\begin{array}{c}\text { Lost at neck } \\
\text { (inch) }\end{array}$ & $\begin{array}{c}\text { Thickness of modified } \\
\text { layer at half down (inch) }\end{array}$ \\
\hline Base glass at $1208^{\circ} \mathrm{C}$ & 0.00182 & 0.01180 & 0.02157 \\
\hline Low-viscosity glass at $1208^{\circ} \mathrm{C}$ & 0.00637 & 0.04400 & 0.03708 \\
\hline Base glass at $1283^{\circ} \mathrm{C}$ & 0.00274 & 0.012261 & 0.02055 \\
\hline
\end{tabular}


Table 6.1. Compositions of the Pristine and the Reacted Glasses after Coupon Corrosion Tests at $1208^{\circ} \mathrm{C}, 1283^{\circ} \mathrm{C}$ and $1389^{\circ} \mathrm{C}$.

\begin{tabular}{|l|r|r|r|r|r|r|}
\hline Glass Name & \multicolumn{2}{|c|}{ HLWD1-4SI } & \multicolumn{2}{c|}{ HLWD1-4SH } & \multicolumn{2}{c|}{ HLWD4SH2R } \\
\hline & \multicolumn{1}{|c|}{ Before } & \multicolumn{1}{c|}{ After } & \multicolumn{1}{c|}{ Before } & \multicolumn{1}{c|}{ After } & Before & After \\
\hline $\mathrm{Al}_{2} \mathrm{O}_{3}$ & 8.25 & 8.93 & 7.7 & 9.7 & 8.68 & 10.06 \\
\hline $\mathrm{B}_{2} \mathrm{O}_{3}$ & 9.03 & 8.75 & 5.57 & 4.63 & 3.37 & 1.83 \\
\hline $\mathrm{BaO}$ & 1.61 & 1.65 & 1.7 & 1.74 & 1.53 & 1.58 \\
\hline $\mathrm{CaO}$ & 8.16 & 8.42 & 8.64 & 8.69 & 8.77 & 9.17 \\
\hline $\mathrm{Cr}_{2} \mathrm{O}_{3}$ & 0.25 & 0.1 & 0.22 & 0.12 & 0.26 & 0.25 \\
\hline $\mathrm{Fe}_{2} \mathrm{O}_{3}$ & 12.07 & 11.63 & 12.66 & 12.22 & 13.19 & 13.09 \\
\hline $\mathrm{K}_{2} \mathrm{O}$ & 0.51 & 0.46 & 0.51 & 0.45 & 0.58 & 0.31 \\
\hline $\mathrm{Li}_{2} \mathrm{O}$ & 1.61 & 1.51 & 1.64 & 1.55 & 1.61 & 1.35 \\
\hline $\mathrm{MgO}$ & 1.06 & 1.16 & 1.15 & 1.27 & 1.26 & 1.56 \\
\hline $\mathrm{MnO}_{2}$ & 3.2 & 3.15 & 3.38 & 3.23 & 3.49 & 3.41 \\
\hline $\mathrm{Na}_{2} \mathrm{O}$ & 7.75 & 7.35 & 7.34 & 7.03 & 7.61 & 6.65 \\
\hline $\mathrm{NiO}^{\mathrm{P}_{2} \mathrm{O}_{5}}$ & 0.87 & 0.64 & 0.75 & 0.59 & 0.91 & 0.72 \\
\hline $\mathrm{SiO}_{2}$ & 1.42 & 1.5 & 1.55 & 1.66 & 1.39 & 1.48 \\
\hline $\mathrm{TiO}_{2}$ & 37.28 & 38.03 & 39.81 & 39.89 & 39.85 & 41.27 \\
\hline $\mathrm{ZnO}^{\mathrm{ZnO} O}$ & 0.69 & 0.7 & 0.71 & 0.75 & 0.88 & 0.87 \\
\hline $\mathrm{ZrO}_{2}$ & 3.09 & 2.76 & 3.2 & 2.95 & 3.27 & 2.93 \\
\hline
\end{tabular}

Table 6.2. Corrosion Loss of K-3 in Glasses of HLWD1-4SL, HLWD1-4SH, and HLWD1-4SH2R.

\begin{tabular}{|l|c|c|c|c|c|c|}
\hline \multicolumn{1}{|c|}{ Glass Name } & Coupon Name & $T\left(^{\circ}\right)$ & $\begin{array}{c}\text { Test } \\
\text { Length } \\
\text { (day) }\end{array}$ & $\begin{array}{c}\text { Neck Loss } \\
\text { (inch) }\end{array}$ & $\begin{array}{c}\text { Half Down } \\
\text { Loss } \\
\text { (inch) }\end{array}$ & $\begin{array}{c}\text { Alteration } \\
\text { Depth } \\
\text { (inch) }\end{array}$ \\
\hline HLWD1-4S1 & K-3-VS & 1208 & 6 & 0.00062 & 0.00008 & 0.0083 \\
\hline HLWD1-4SH & K-3-VH & 1283 & 6 & 0.00142 & 0.00032 & 0.00894 \\
\hline HLWD14SH2R & K-3-VH2 & 1389 & 6 & 0.01037 & 0.00028 & 0.01774 \\
\hline
\end{tabular}


Table 6.3. Table of Glass Composition Before and After Corrosion.

\begin{tabular}{|c|c|c|c|c|c|c|c|c|c|c|}
\hline Glass Name & WVR & EF6 & WVRE & F6B & WVRI & $3-\mathrm{K} 3$ & WVRE & $\mathrm{R}-\mathrm{K} 3$ & SRL & EA \\
\hline & Before & After & Before & After & Before & After & Before & After & Before & After \\
\hline $\mathrm{Al}_{2} \mathrm{O}_{3}$ & 5.41 & 6.62 & 5.41 & 6.20 & 5.41 & 8.57 & 5.41 & 8.42 & 3.41 & 6.93 \\
\hline$\overline{\mathrm{B}_{2} \mathrm{O}_{3}}$ & 14.48 & 13.02 & 14.48 & 14.14 & 14.48 & 12.23 & 14.48 & 12.20 & 11.3 & 9.93 \\
\hline$\overline{\mathrm{CaO}}$ & 0.68 & 0.7 & 0.68 & 0.62 & 0.68 & 0.71 & 0.68 & 0.64 & 1.14 & 1.25 \\
\hline $\mathrm{Cr}_{2} \mathrm{O}_{3}$ & 0.14 & 0.25 & 0.14 & 0.12 & 0.14 & 0.35 & 0.14 & 0.35 & 0.31 & 0.87 \\
\hline $\mathrm{Fe}_{2} \mathrm{O}_{3}$ & 12.16 & 12.63 & 12.16 & 11.72 & 12.16 & 11.85 & 12.16 & 12.05 & 10.82 & 9.04 \\
\hline $\mathrm{K}_{2} \mathrm{O}$ & 5.03 & 4.18 & 5.03 & 5.20 & 5.03 & 4.01 & 5.03 & 4.41 & 0.06 & $\overline{0.11}$ \\
\hline $\mathrm{Li}_{2} \mathrm{O}$ & 4.11 & 3.71 & 4.11 & 3.79 & 4.11 & 3.44 & 4.11 & 3.56 & 4.26 & 3.97 \\
\hline$\overline{\mathrm{MgO}}$ & 1.01 & 1.13 & 1.01 & 0.90 & 1.01 & 1.12 & 1.01 & 1.12 & 1.61 & 2.1 \\
\hline $\mathrm{MnO}_{2}$ & 1.18 & 1.1 & 1.18 & 1.10 & 1.18 & 1.00 & 1.18 & 1.04 & 1.55 & 1.66 \\
\hline $\mathrm{Na}_{2} \mathrm{O}$ & 8.26 & 7.46 & 8.26 & $\overline{8.15}$ & 8.26 & 7.23 & 8.26 & 7.73 & 16.86 & 14.32 \\
\hline $\mathrm{NiO}$ & 0.26 & 0.23 & 0.26 & 0.24 & 0.26 & 0.20 & $\overline{0.26}$ & 0.21 & 0.78 & \begin{tabular}{|l|l|}
0.49 \\
\end{tabular} \\
\hline$\overline{\mathrm{P}_{2} \mathrm{O}_{5}}$ & 1.27 & 1.34 & 1.27 & 1.27 & 1.27 & 1.26 & 1.27 & 1.28 & 0.02 & 0.1 \\
\hline $\mathrm{SiO}_{2}$ & 43.47 & 45.18 & 43.47 & 43.97 & 43.47 & 44.87 & 43.47 & \begin{tabular}{|l}
4.44 \\
\end{tabular} & 45.93 & 47.55 \\
\hline $\mathrm{SrO}$ & 0.02 & 0 & 0.02 & 0.03 & 0.02 & 0.03 & 0.02 & 0.03 & 0.01 & $\overline{0.02}$ \\
\hline $\mathrm{TiO}_{2}$ & $\overline{0.9}$ & $\overline{0.88}$ & 0.9 & 0.87 & 0.9 & 0.91 & 0.9 & 0.88 & 0.77 & $\overline{0.77}$ \\
\hline $\mathrm{ZnO}$ & 0.04 & 0.03 & 0.04 & 0.04 & 0.04 & 0.05 & $\overline{0.04}$ & 0.02 & 0.04 & 0.05 \\
\hline $\mathrm{ZrO}_{2}$ & 1.35 & 1.31 & 1.35 & 1.32 & 1.35 & 1.38 & 1.35 & 1.28 & 0.56 & 0.53 \\
\hline Sum & 99.77 & 100 & 99.77 & 99.68 & 99.77 & 99.21 & 99.77 & 99.66 & 99.43 & 94.92 \\
\hline
\end{tabular}

Table 6.4. K-3 Corrosion Test.

\begin{tabular}{|l|c|c|c|c|c|c|}
\hline Glass Name & Coupon Name & T $\left(^{\circ}\right)$ & $\begin{array}{c}\text { Test } \\
\text { Length } \\
\text { (day) }\end{array}$ & $\begin{array}{c}\text { Neck Loss } \\
\text { (inch) }\end{array}$ & $\begin{array}{c}\text { Half Down } \\
\text { Loss } \\
\text { (inch) }\end{array}$ & $\begin{array}{c}\text { Alteration } \\
\text { Depth } \\
\text { (inch) }\end{array}$ \\
\hline WVREF6 Glass & K-3F & 1208 & 6 & 0.020175 & 0.00115 & 0.02615 \\
\hline WVREF6 Glass & K-3N & 1208 & 6 & 0.01372 & 0.00236 & 0.02540 \\
\hline WVREF6 Glass & K-3WV1 & 1208 & 6 & 0.01566 & 0.00329 & 0.02502 \\
\hline WVREF6 Glass & K-3-WV2 & 1208 & 6 & 0.02097 & 0.00283 & 0.02531 \\
\hline SRL-EA Glass & SRL-EA-K3 & 1208 & 6 & 0.08663 & 0.01520 & 0.02858 \\
\hline
\end{tabular}




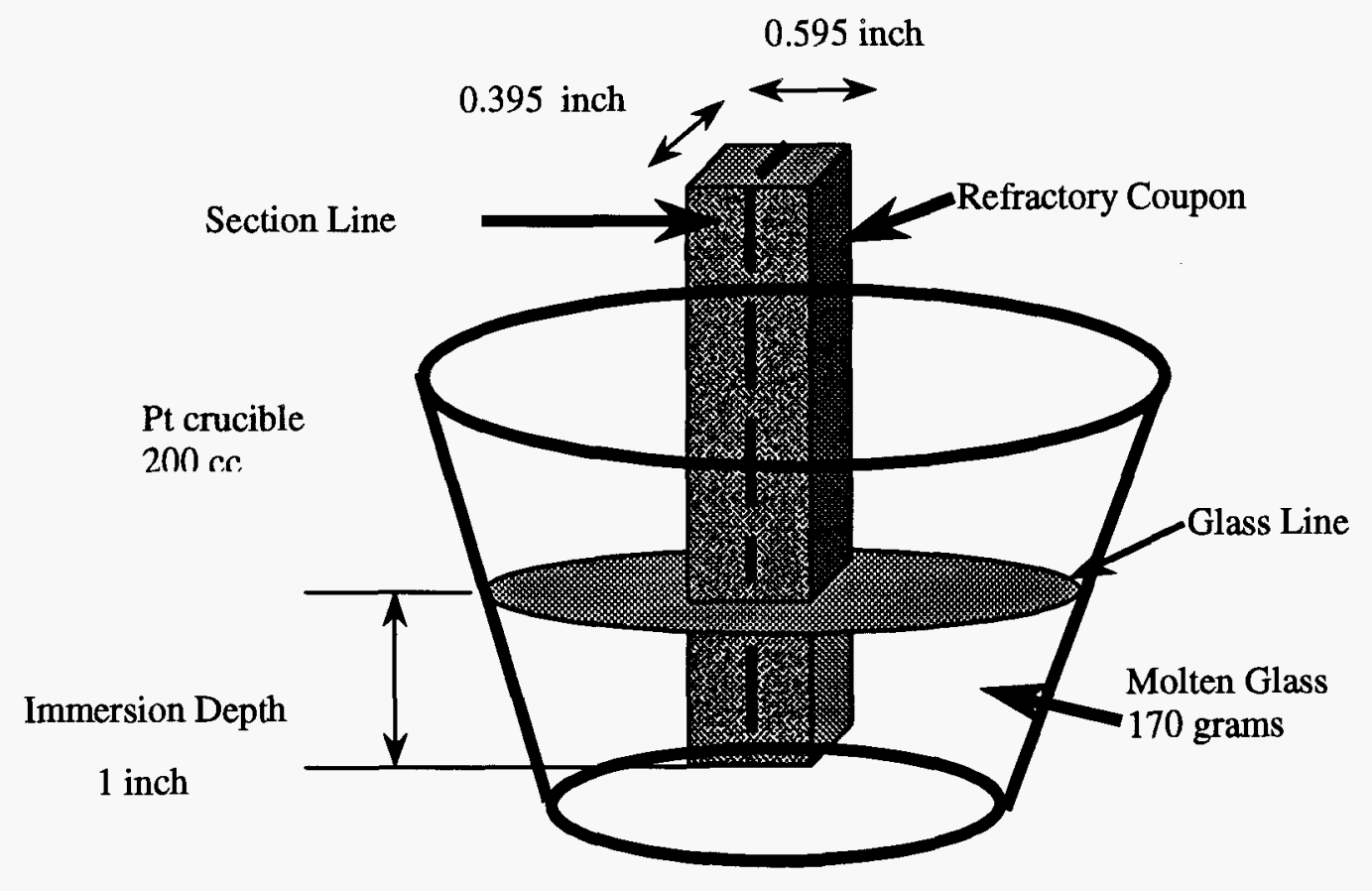

Figure 3.1. Refractory test coupon for standard glass contact corrosion. 


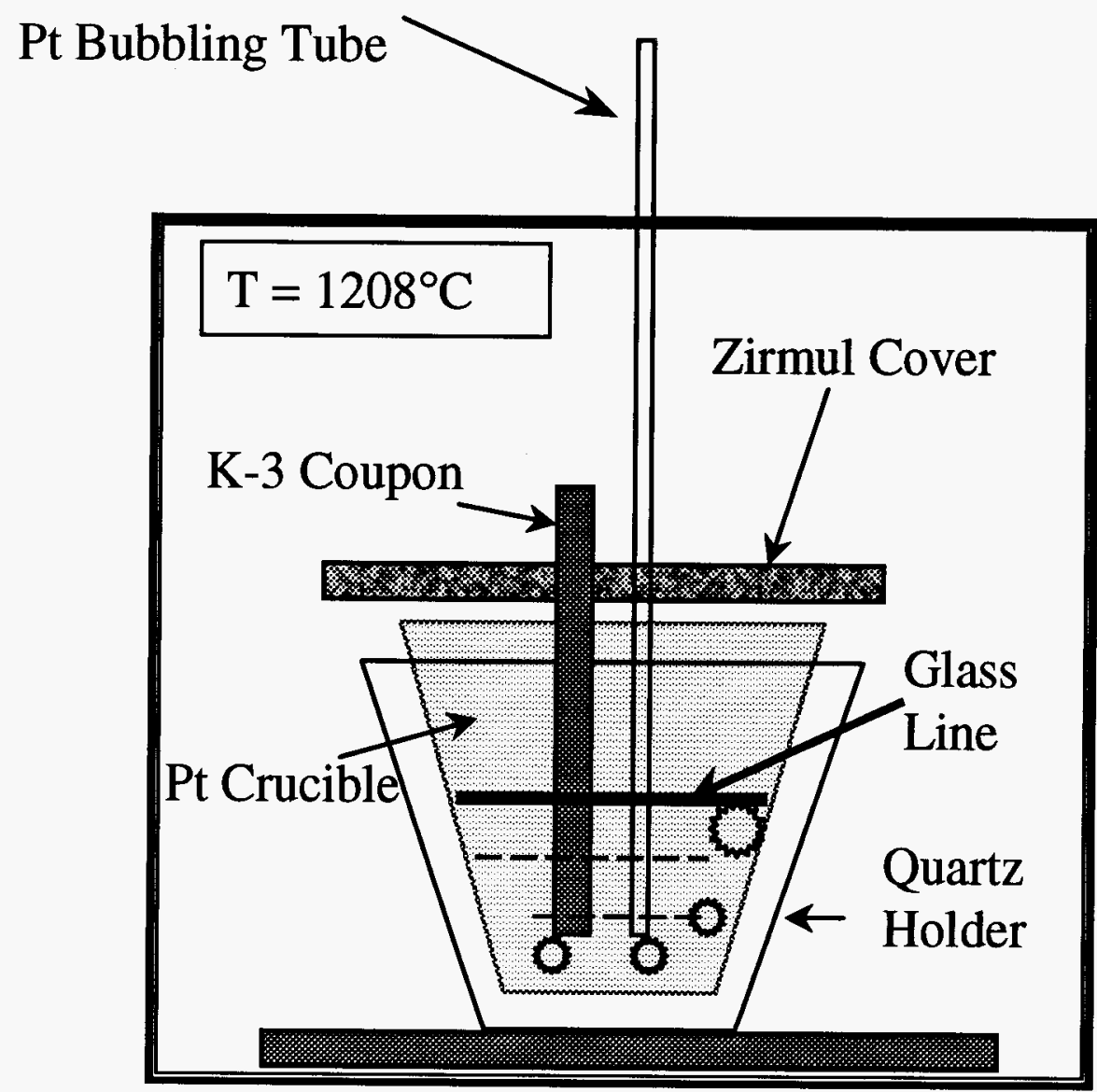

Figure 3.2. Experiment setup for standard coupon corrosion test with air bubbling agitation. 

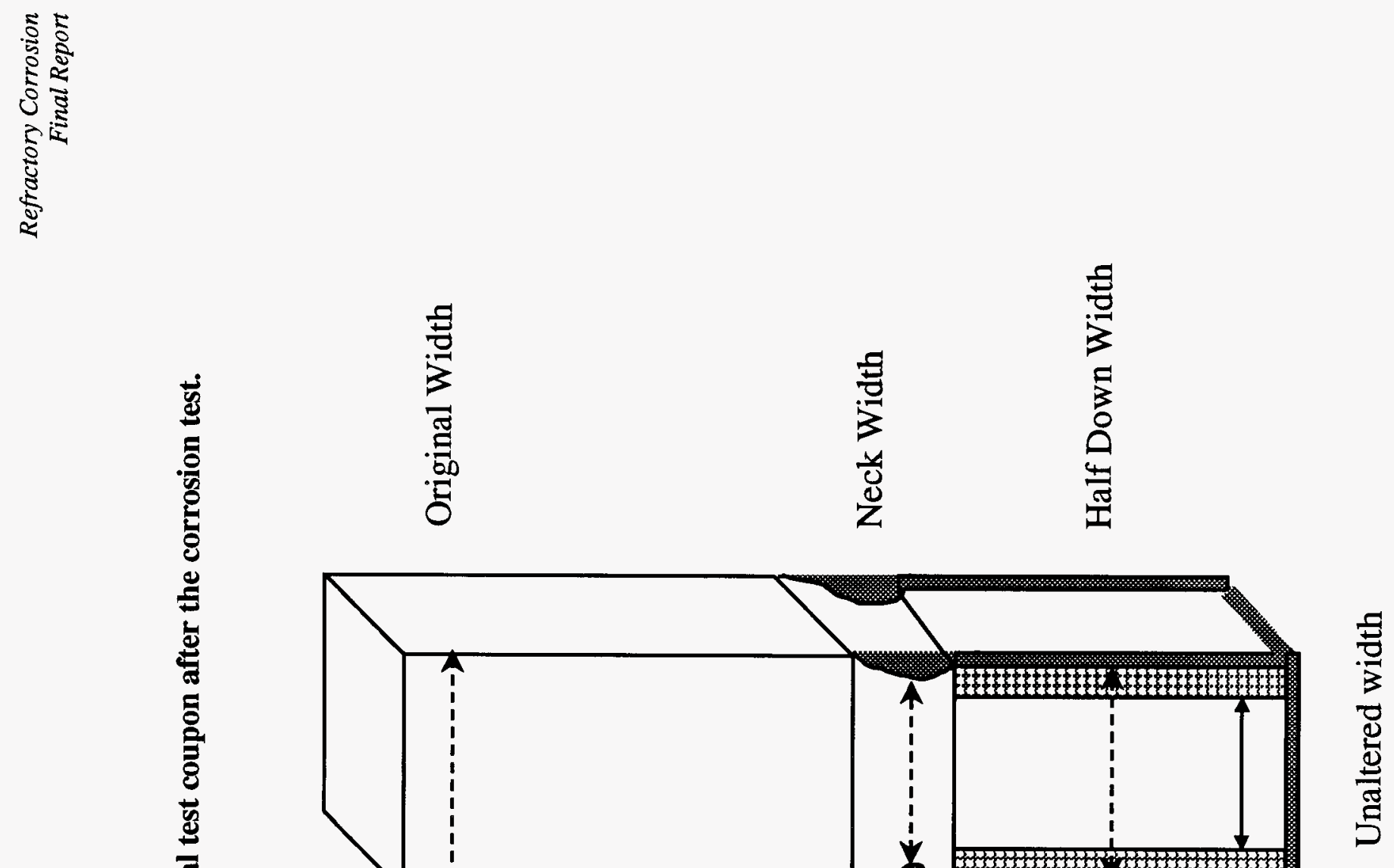



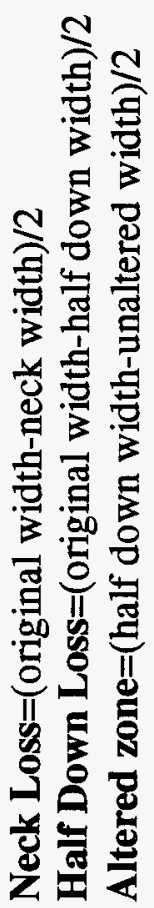




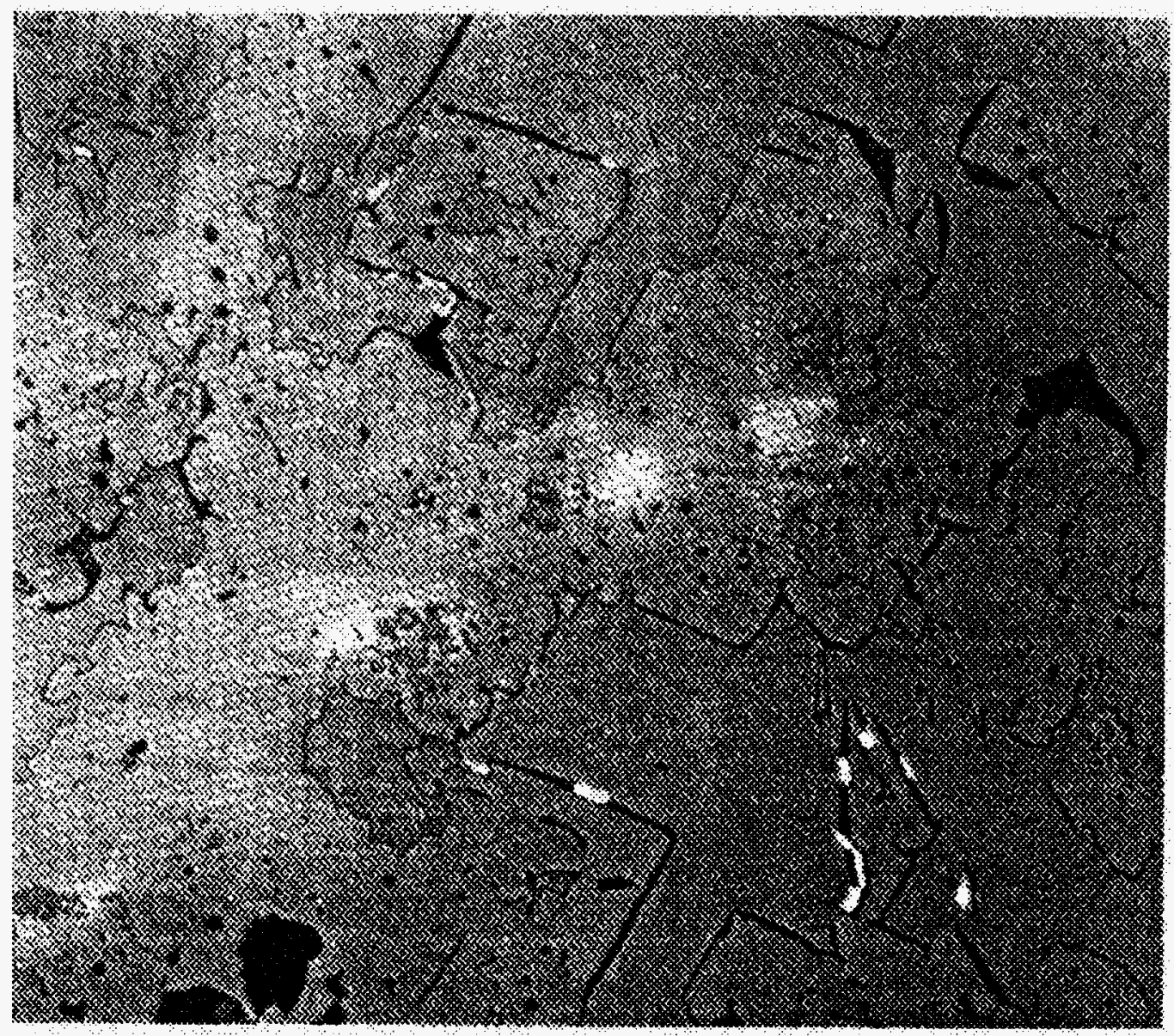

Figure 4.1. Micrograph of pristine type K-3 refractory (from the product information of Carborundum, Form A-2850). 


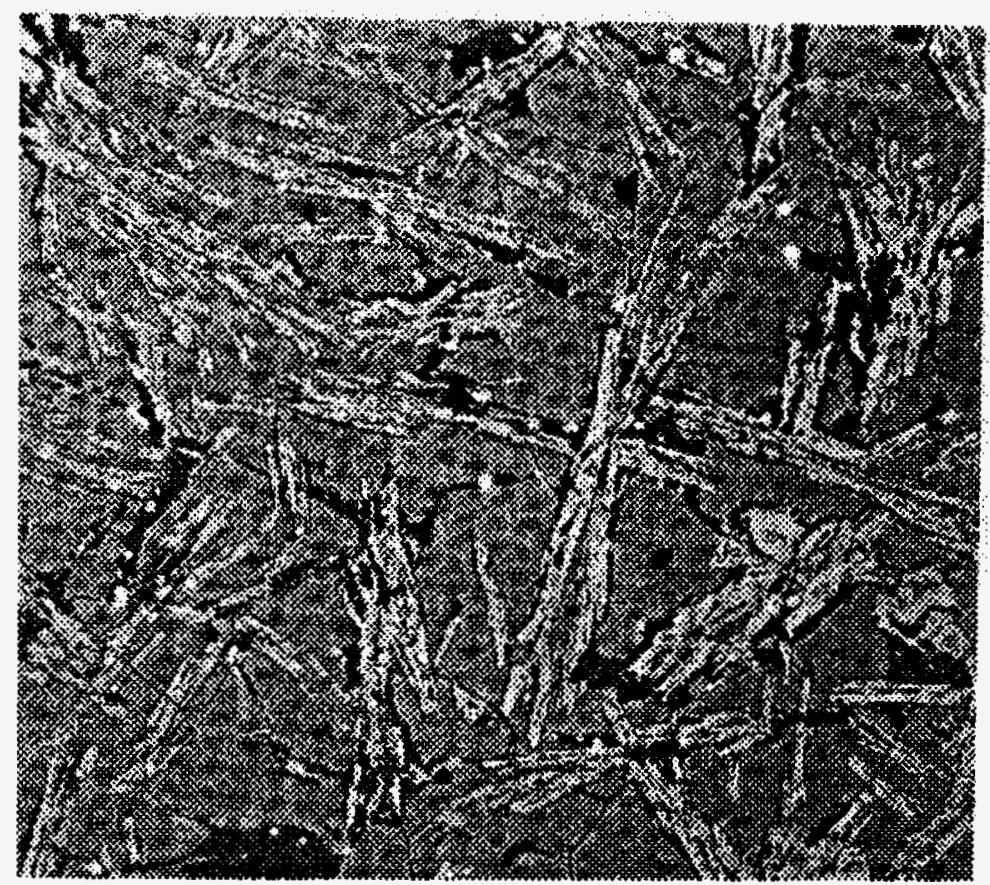

Figure 4.2. Micrograph of pristine type $E$ refractory (from the product information of Carborundum, Form A-2848. 


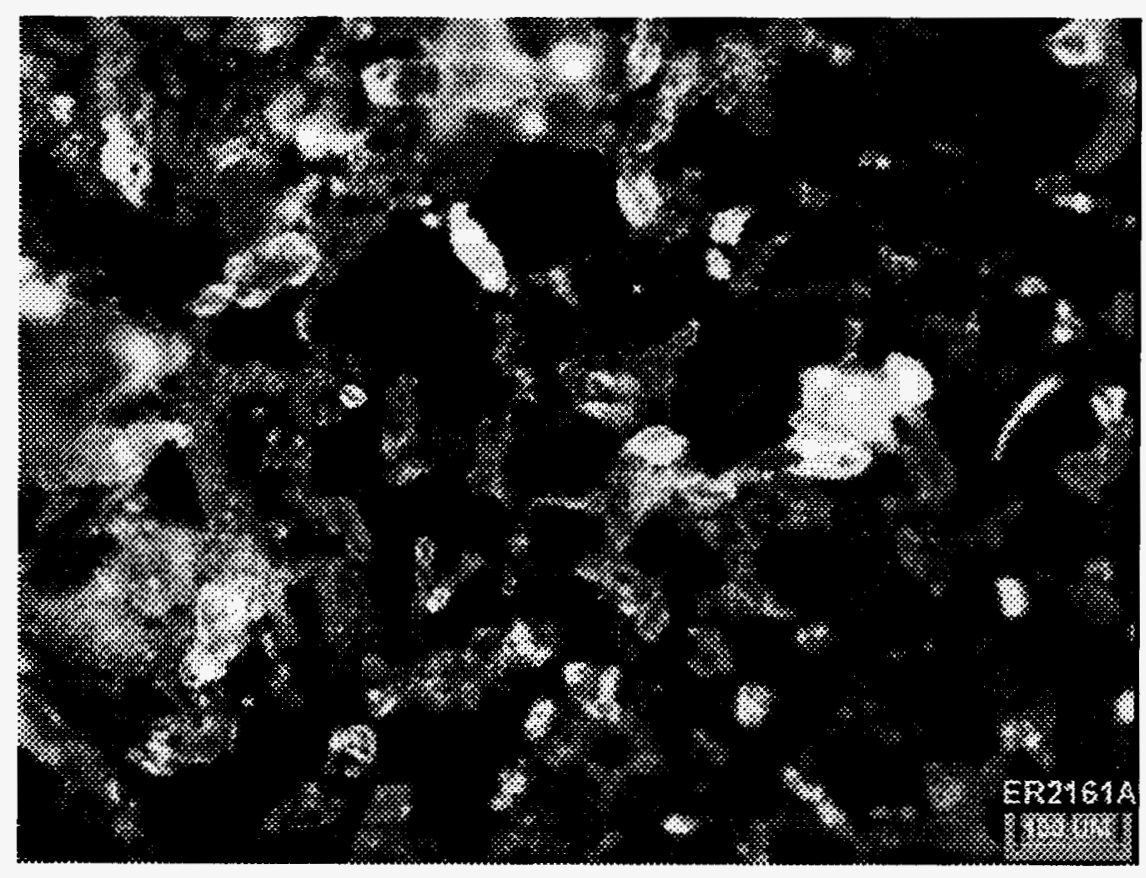

Figure 4.3. Micrograph of pristine ER2161. 


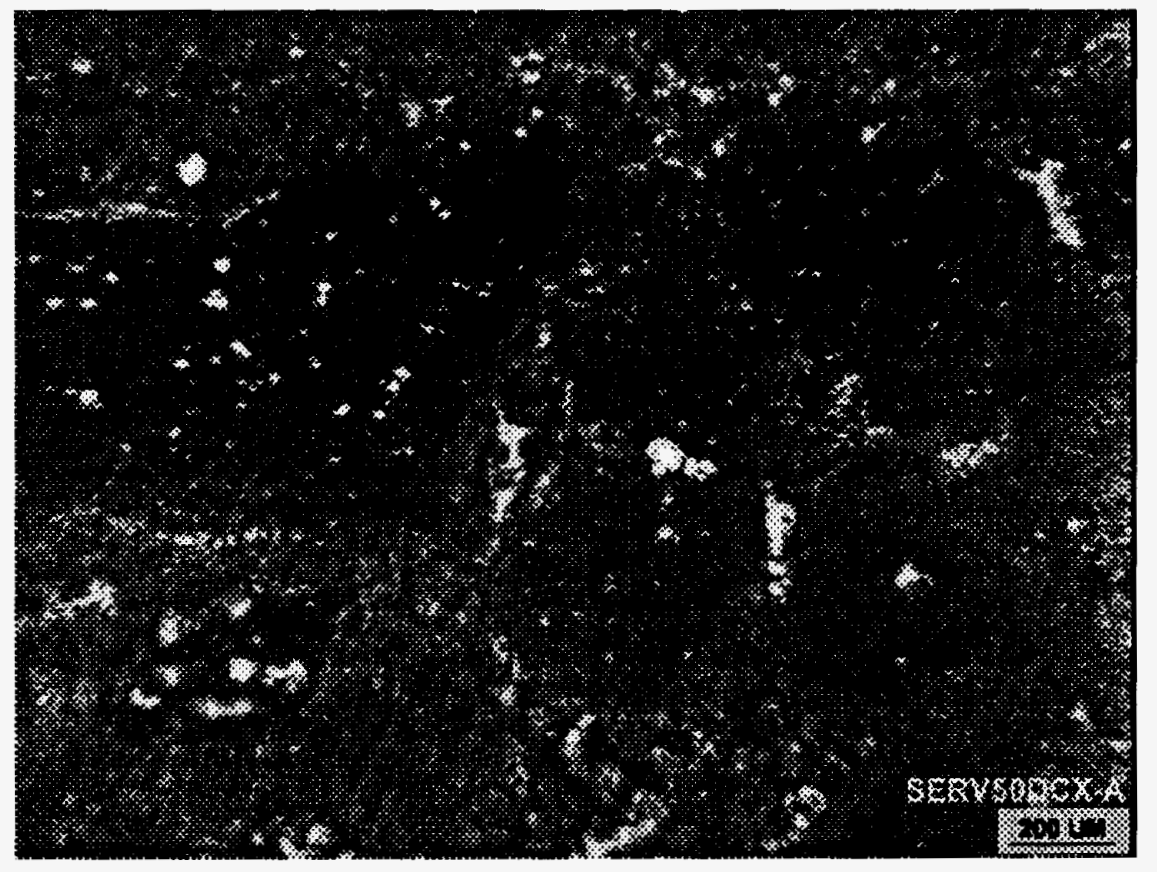

Figure 4.4. Micrograph of pristine SERV50DCX. 


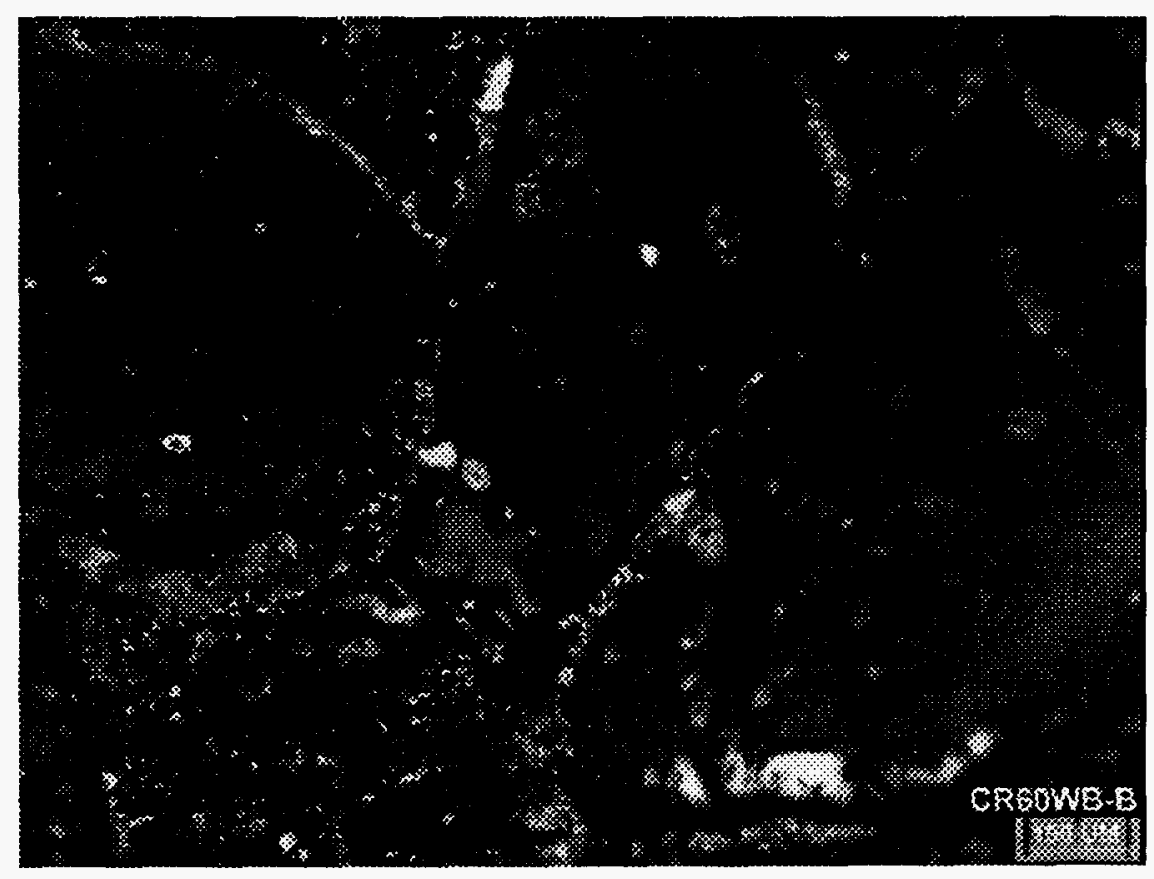

Figure 4.5. Micrograph of pristine CR60WB 


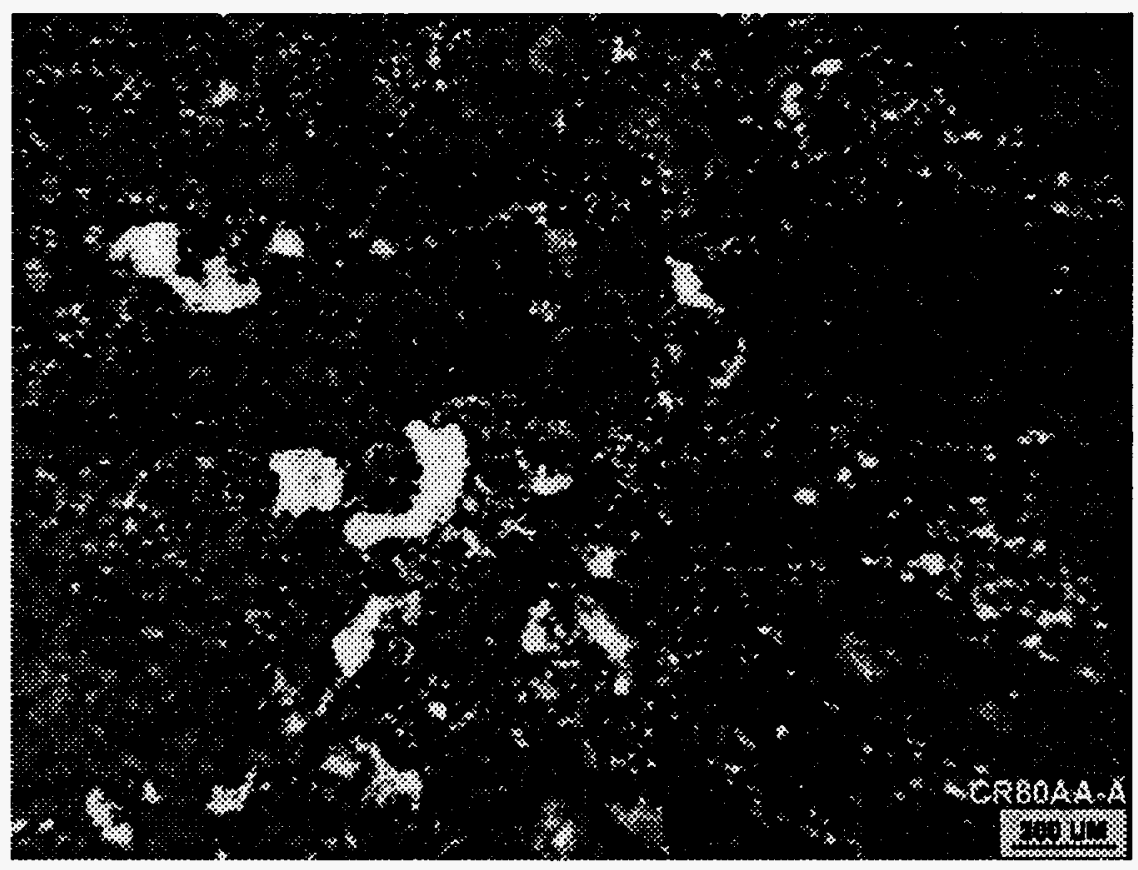

Figure 4.6. Micrograph of pristine CR80AA. 
a)

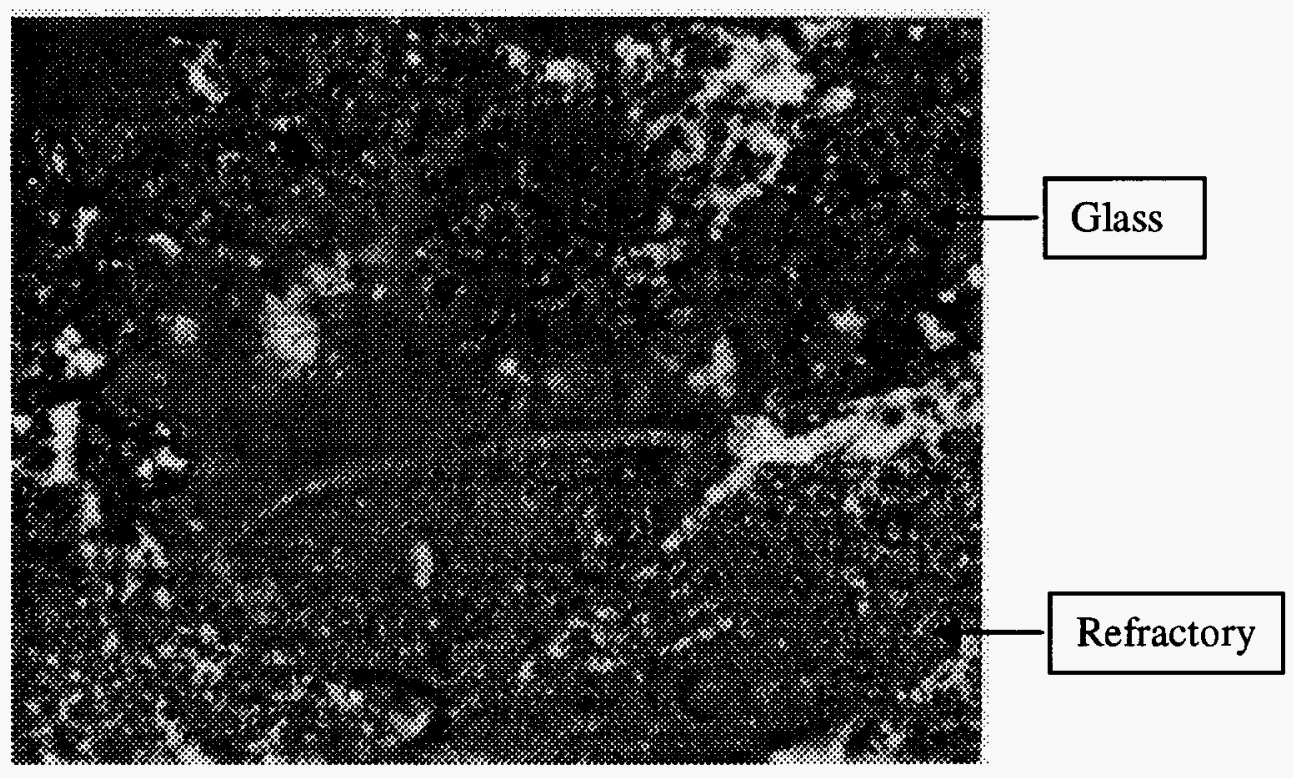

b)

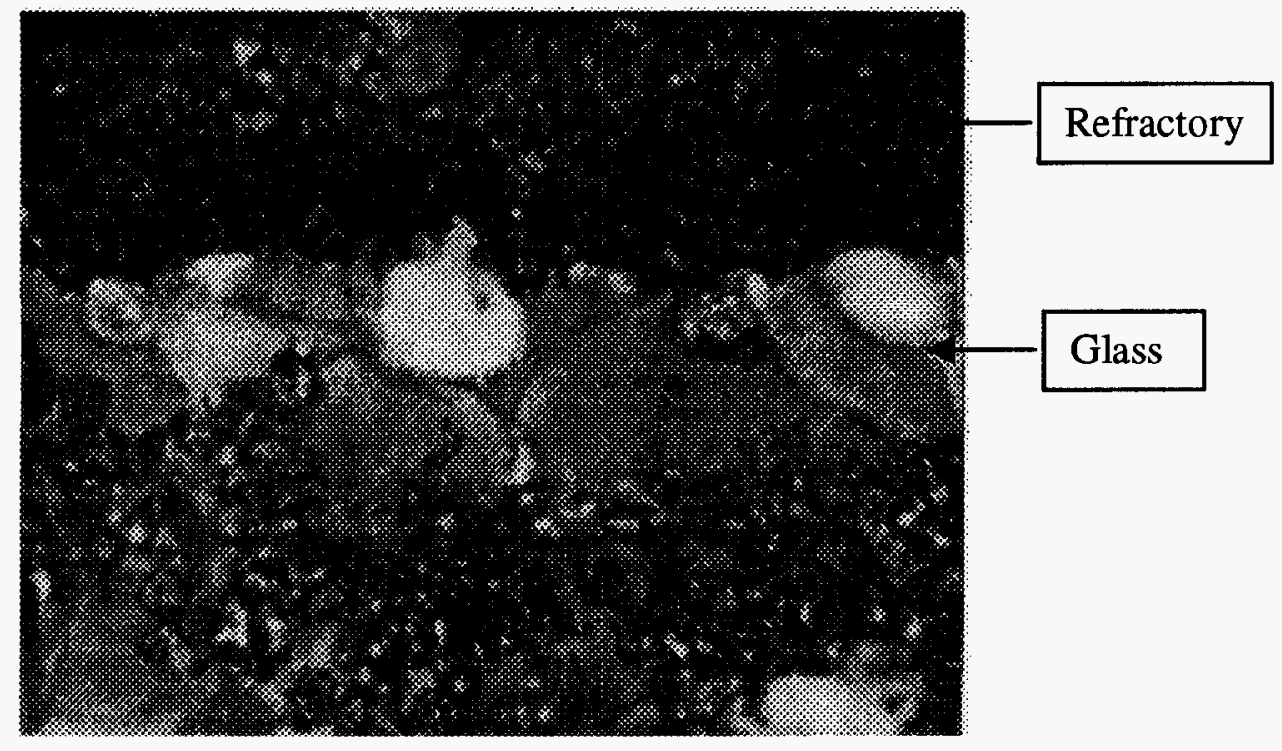

Figure 4.7(a)-(b). Two press-cast VGT-Dyco refractory coupons after the six-day corrosion test. a) CR60WB, b) CR80AA. Note that the refractory coupons near the surface had been severely damaged, became loose and, in turn, were surrounded by the infiltrating glass melts. 


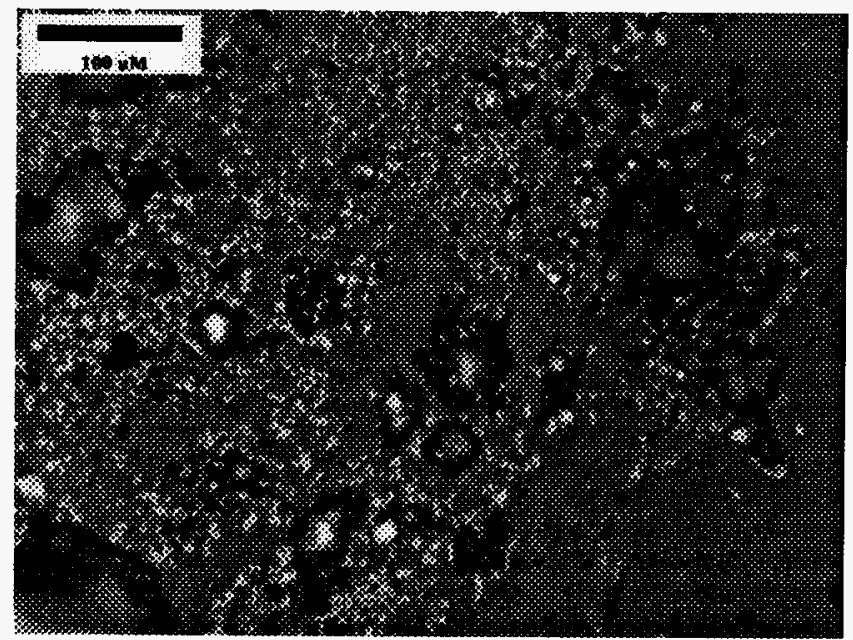

a)

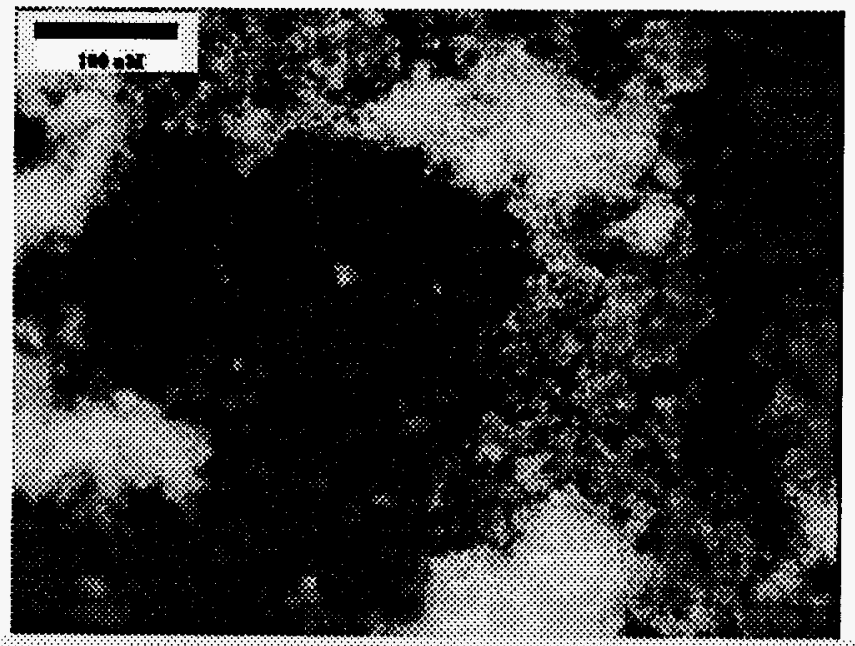

b)

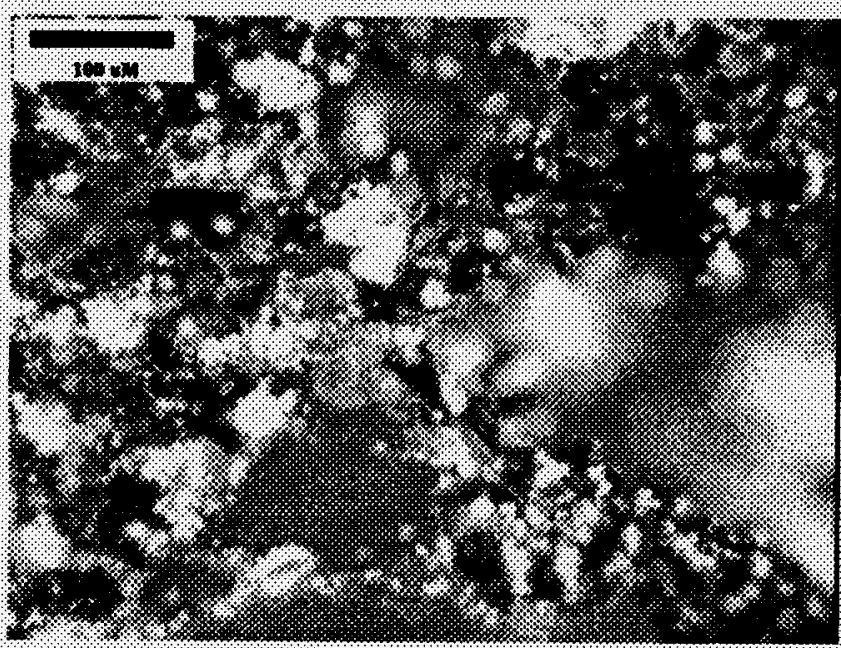

c)

Figure 4.8 (a)-(c). Near surface alteration of SERV50DCX (a), CR60WB (b) and CR80AA (c). The structure for the three refractory coupons had been severely damaged. 
a)

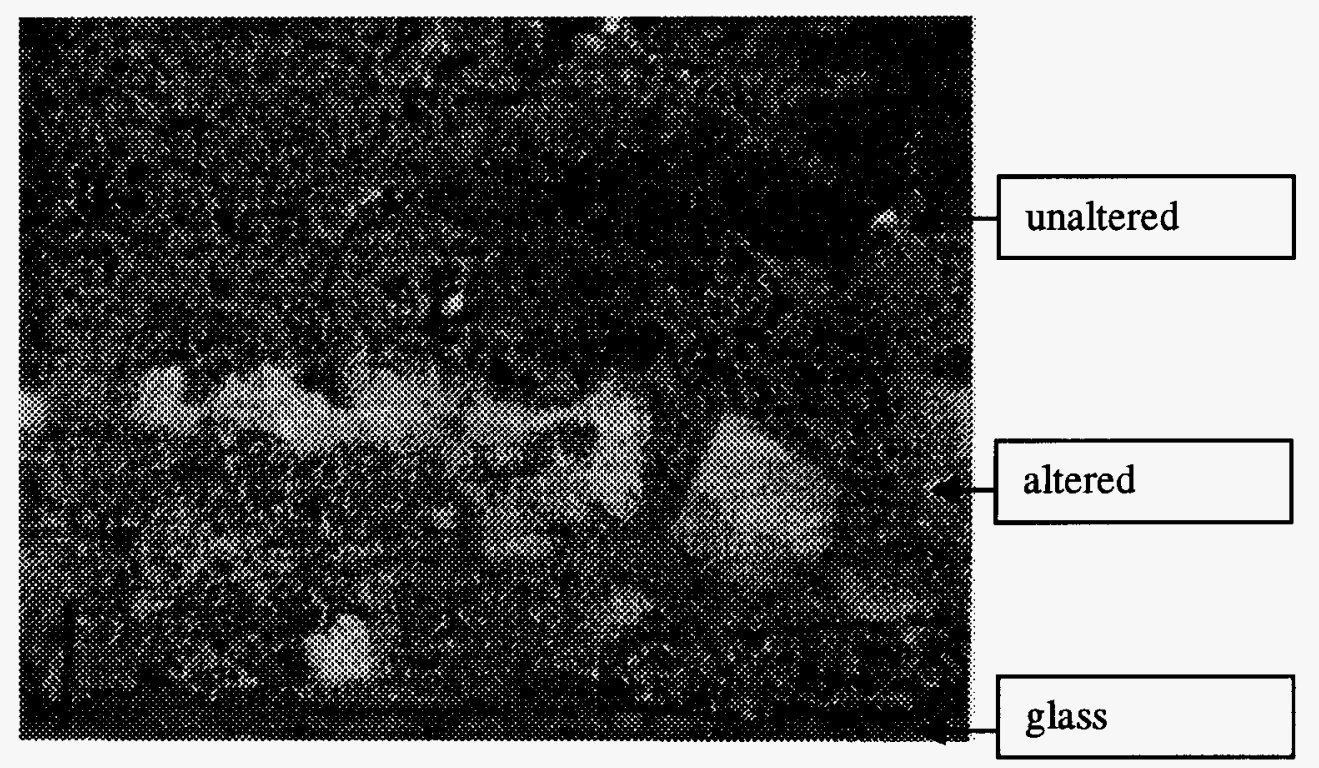

b)

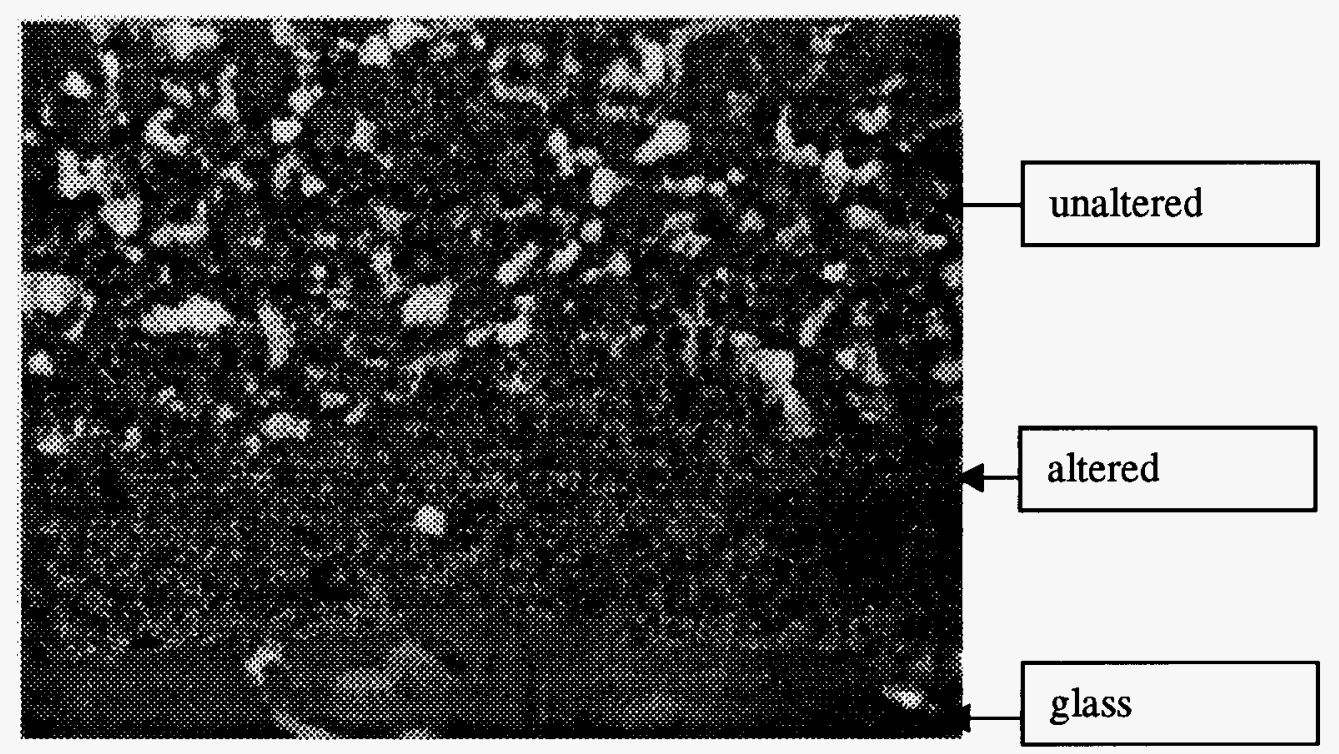

Figure 4.9. (a)-(b). Near surface alteration of K-3 (a) and ER2161 (b). Note that a layer of high chromium spinel formed inside the refractories as the results of glass corrosion reactions for both K-3 and ER2161. 


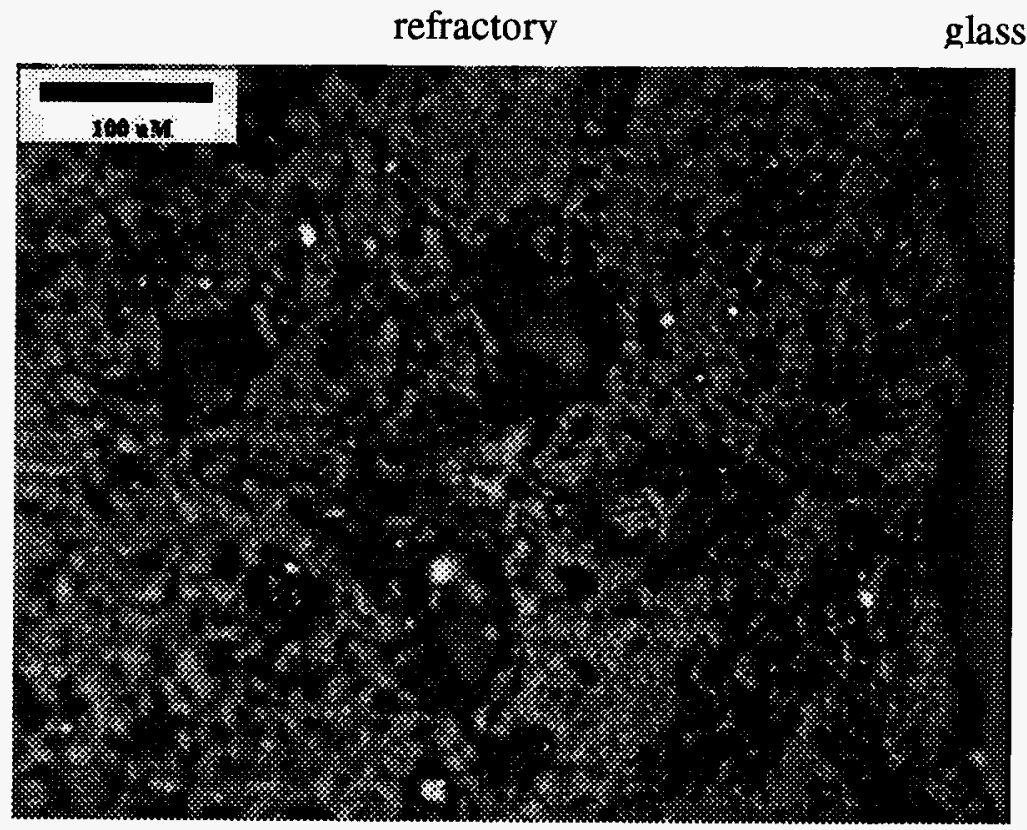

Figure 4.10. No significant alteration was observed near the surface of the type $E$ refractory. 
a)

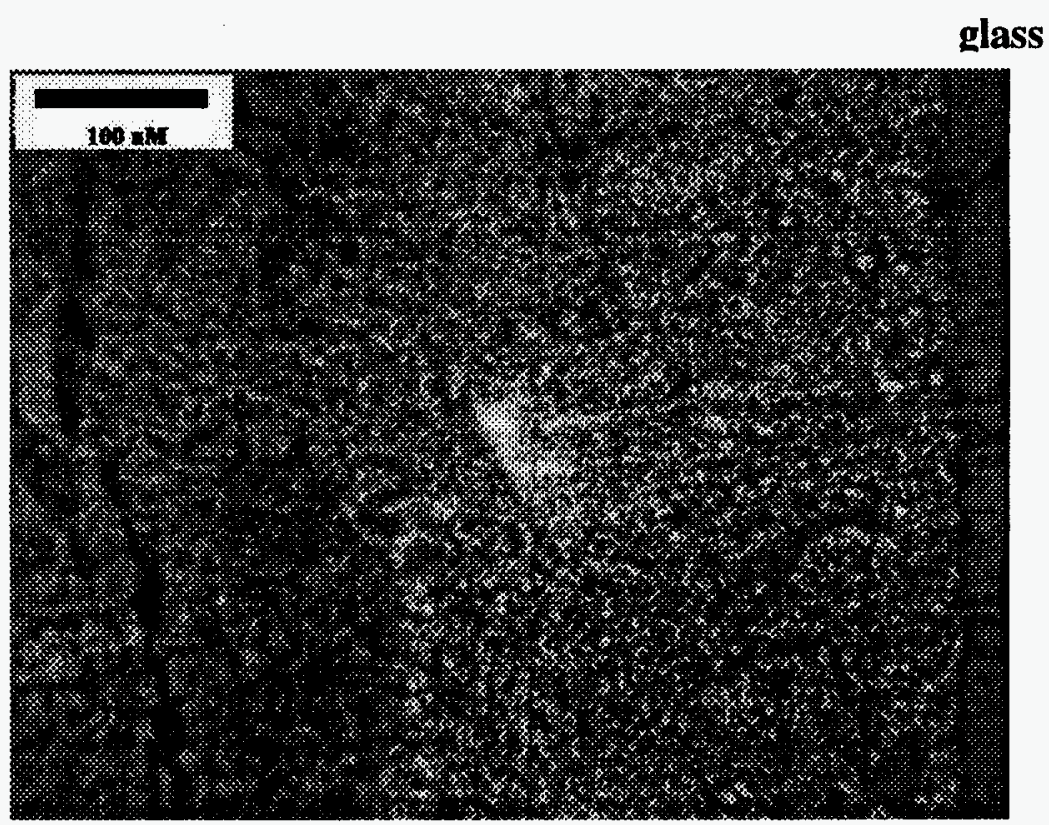

b)

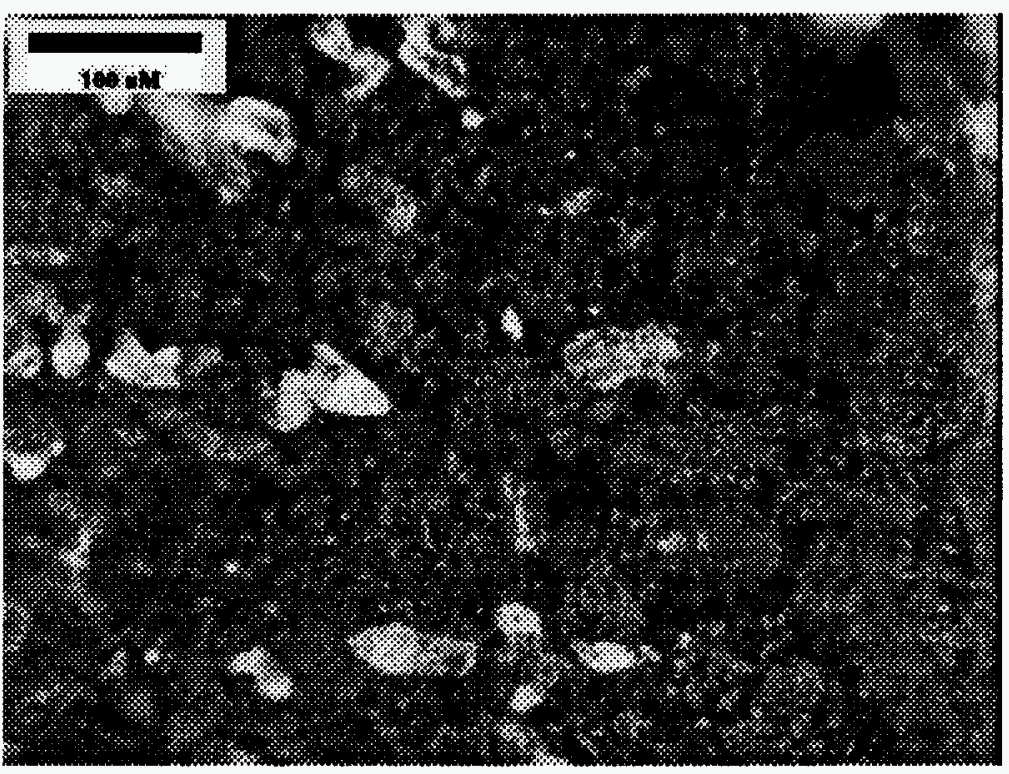

glass

Figure 4.11(a)-(b). Near surface alteration of K-3 (a) and ER2161 (b). The light colored peanut-shaped material about $\mathbf{1 5 0}$ micron away from the surface of the reacted ER2161 is baddeleyite $\left(\mathrm{ZrO}_{2}\right)$. 


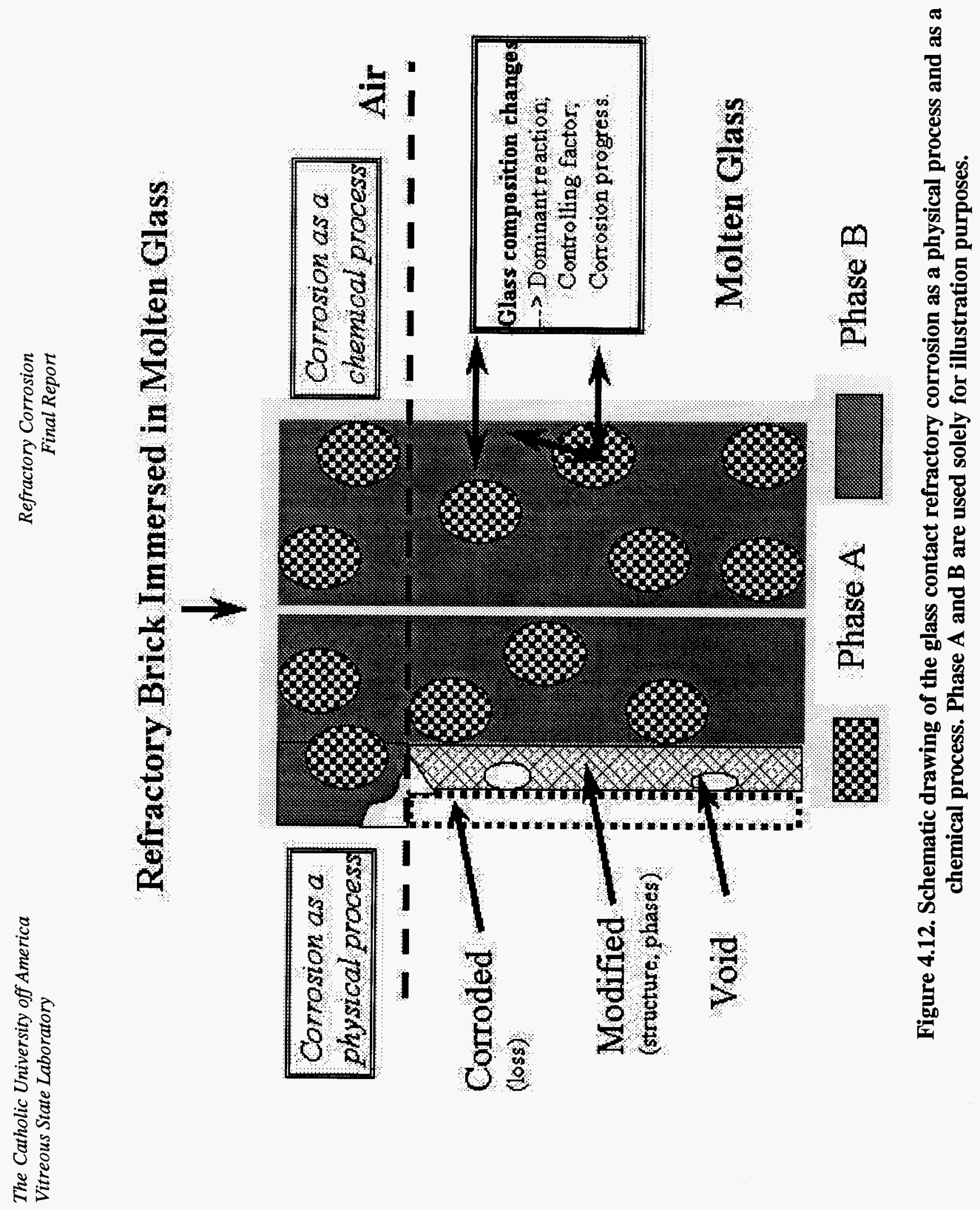




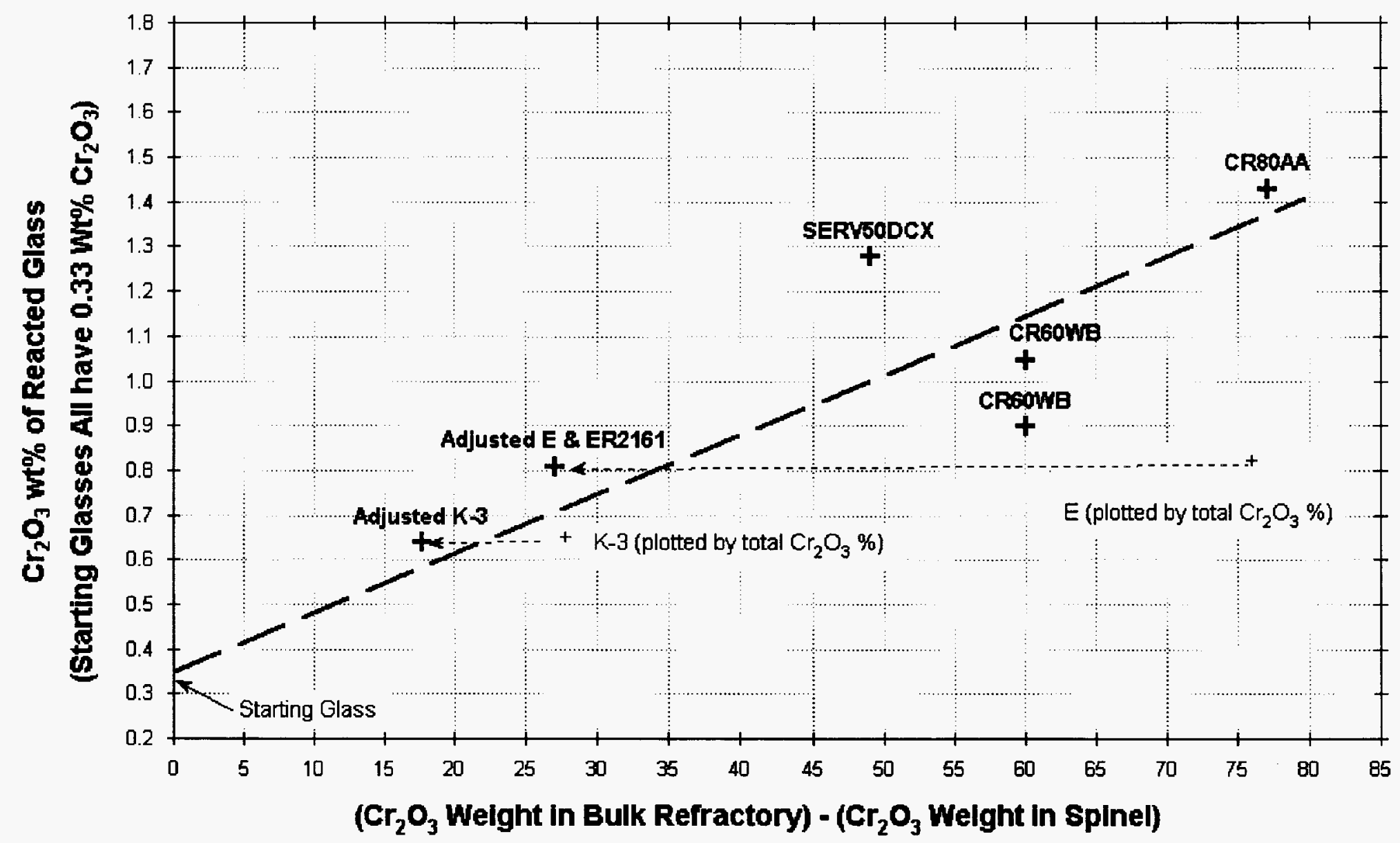

Figure 4.13. The $\mathrm{Cr}_{2} \mathrm{O}_{3}$ concentration in the reacted glass increases with the bulk refractory $\mathrm{Cr}_{2} \mathrm{O}_{3}$ contents from the non-spinel phases. The bulk refractory $\mathrm{Cr}_{2} \mathrm{O}_{3}$ contents from both the non-spinel phases and the spinel phase were also plotted as small cross symbols for $\mathrm{K}-3$ and $\mathrm{E}$ for comparison. 


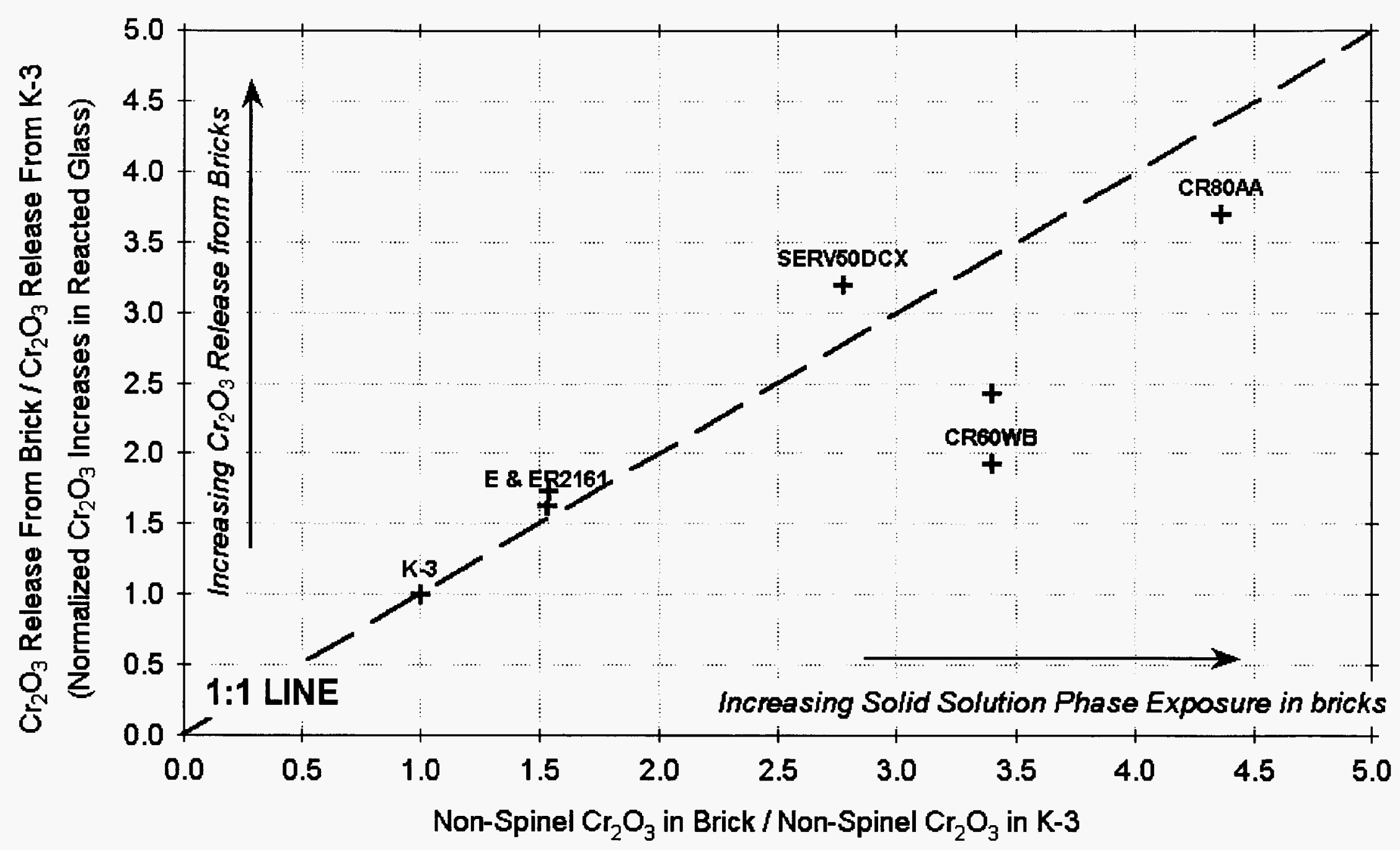

Figure 4.14. The relationship between the normalized $\mathrm{Cr}_{2} \mathrm{O}_{3}$ releases from the test coupon (calculated based on the glass analysis after corrosion tests) and the normalized $\mathrm{Cr}_{2} \mathrm{O}_{3}$ contents in the refractory materials

(calculated based on the refractory analysis before corrosion test). 


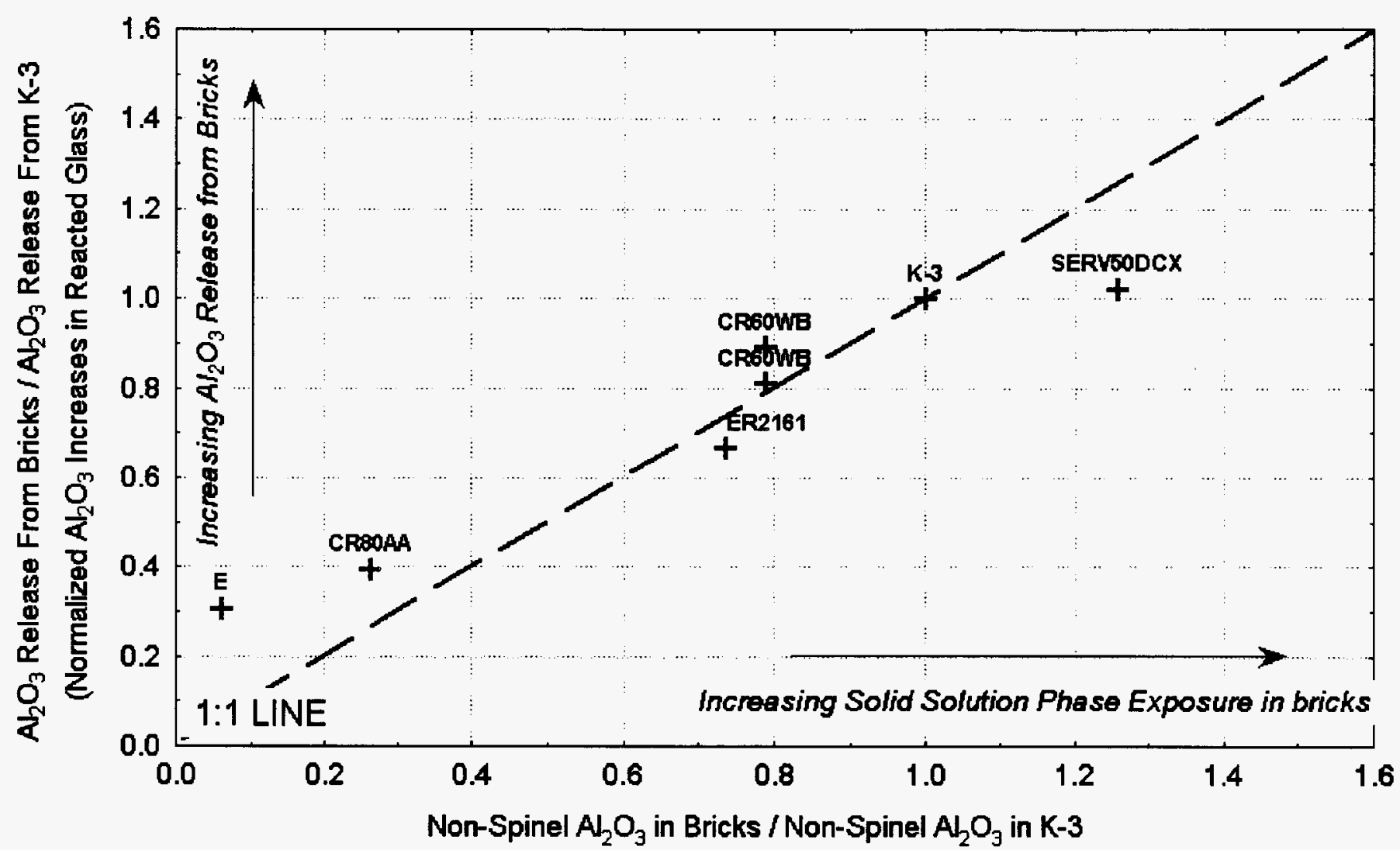

Figure 4.15. The relationship between the normalized $\mathrm{Al}_{2} \mathrm{O}_{3}$ releases from the test coupon (calculated based on the glass analysis after corrosion tests) and the normalized $\mathrm{Al}_{2} \mathrm{O}_{3}$ contents in the refractory materials (calculated based on the refractory analysis before corrosion test). 


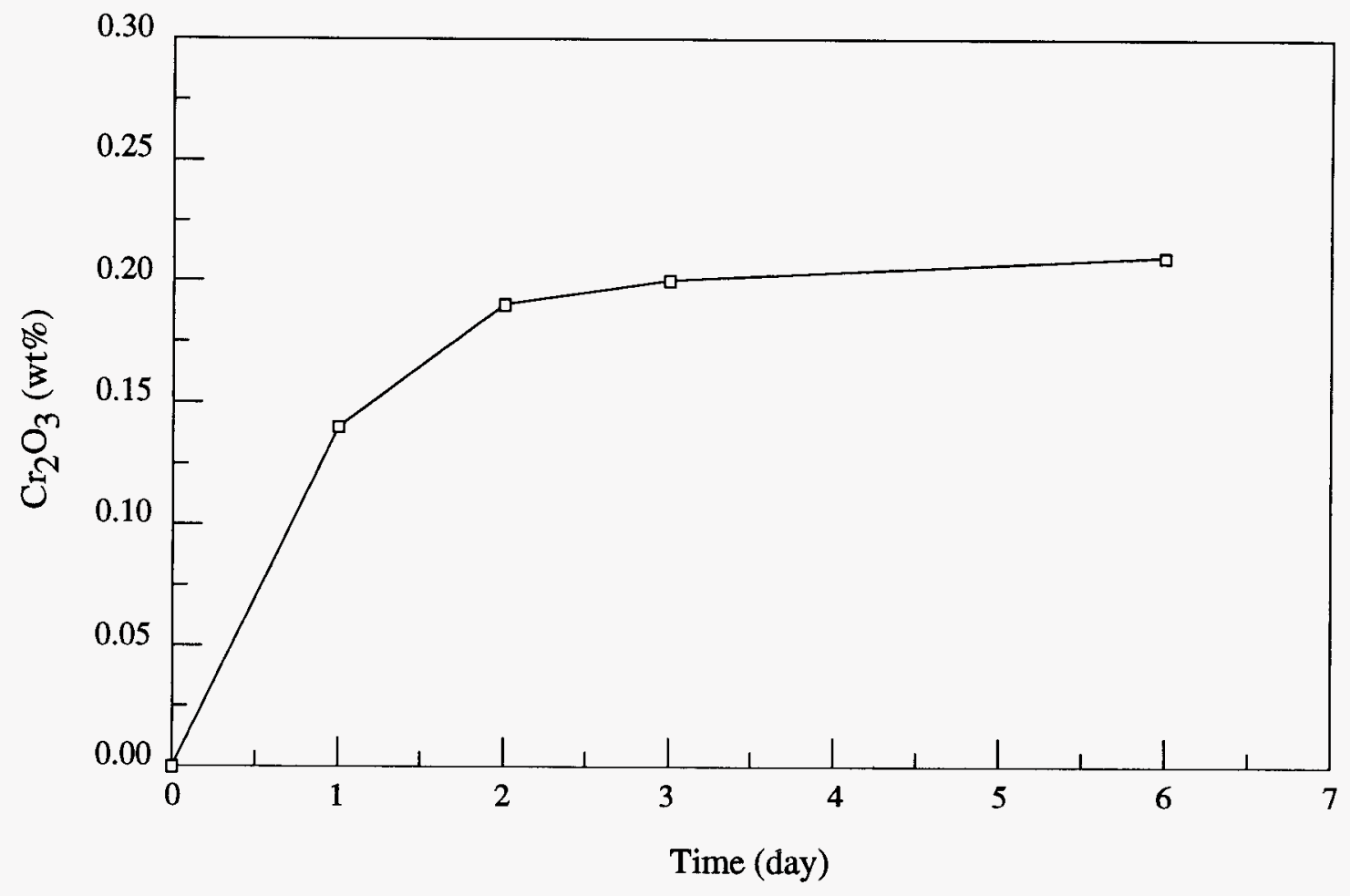

Figure 5.1. Time dependence of $\mathrm{Cr}_{2} \mathrm{O}_{3}$ contents of glass reacted with $\mathrm{K}-3$ coupon at $1208^{\circ} \mathrm{C}$. 


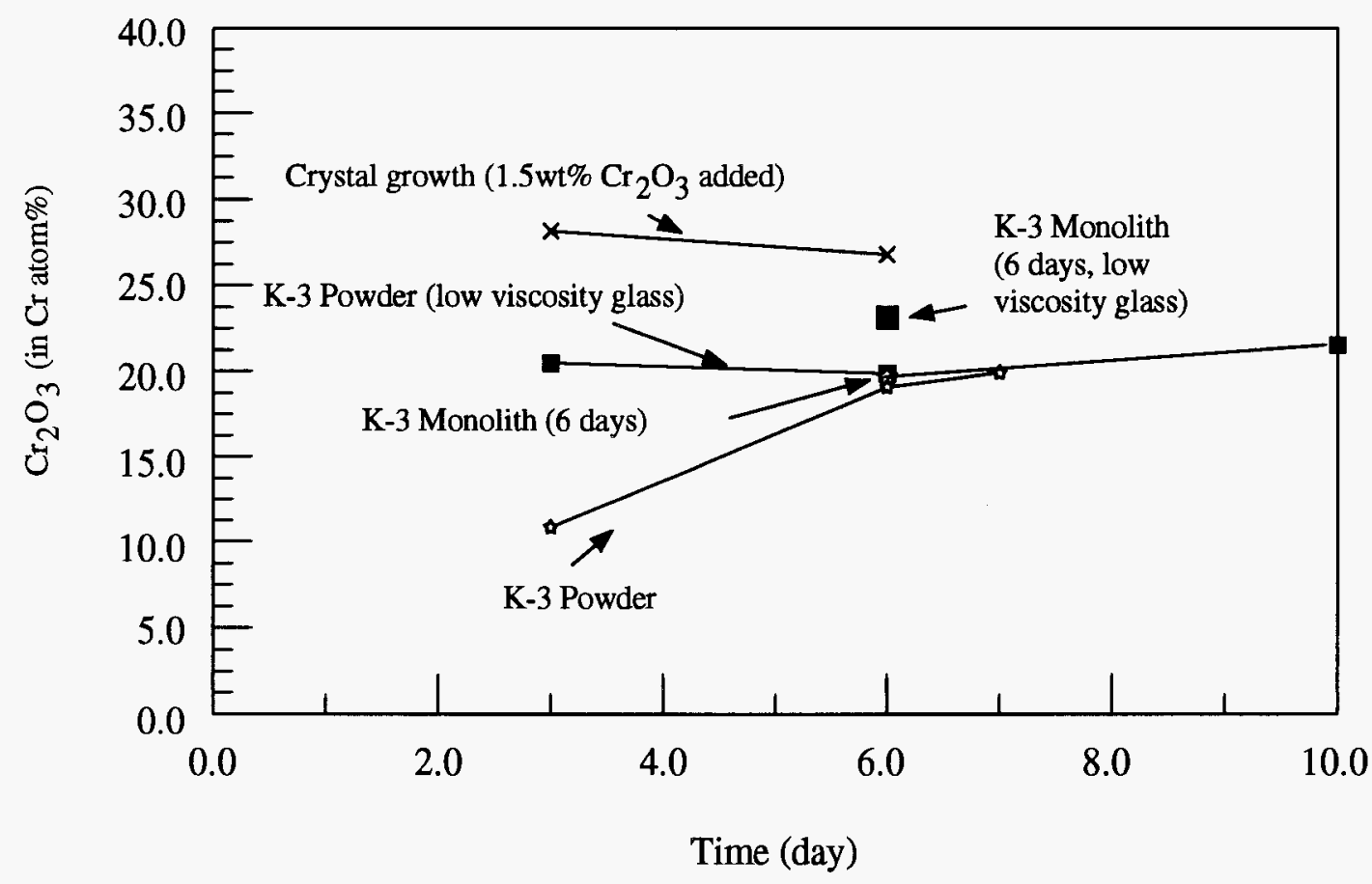

Figure 5.2. Variation of composition of interface spinel with time at $1208^{\circ} \mathrm{C}$. 


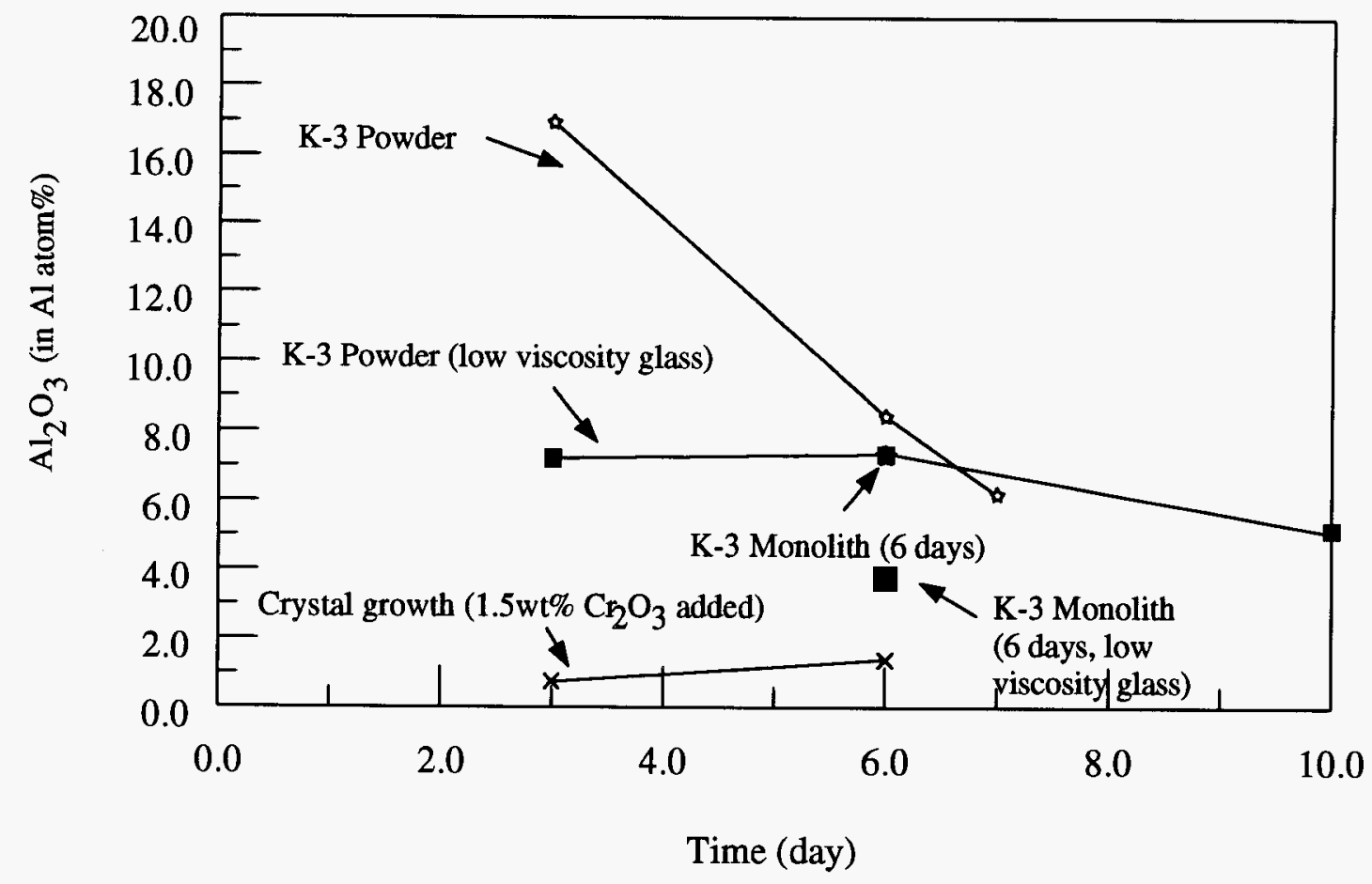

Figure 5.3. Variation of composition of interface spinel with time at $1208^{\circ} \mathrm{C}$. 


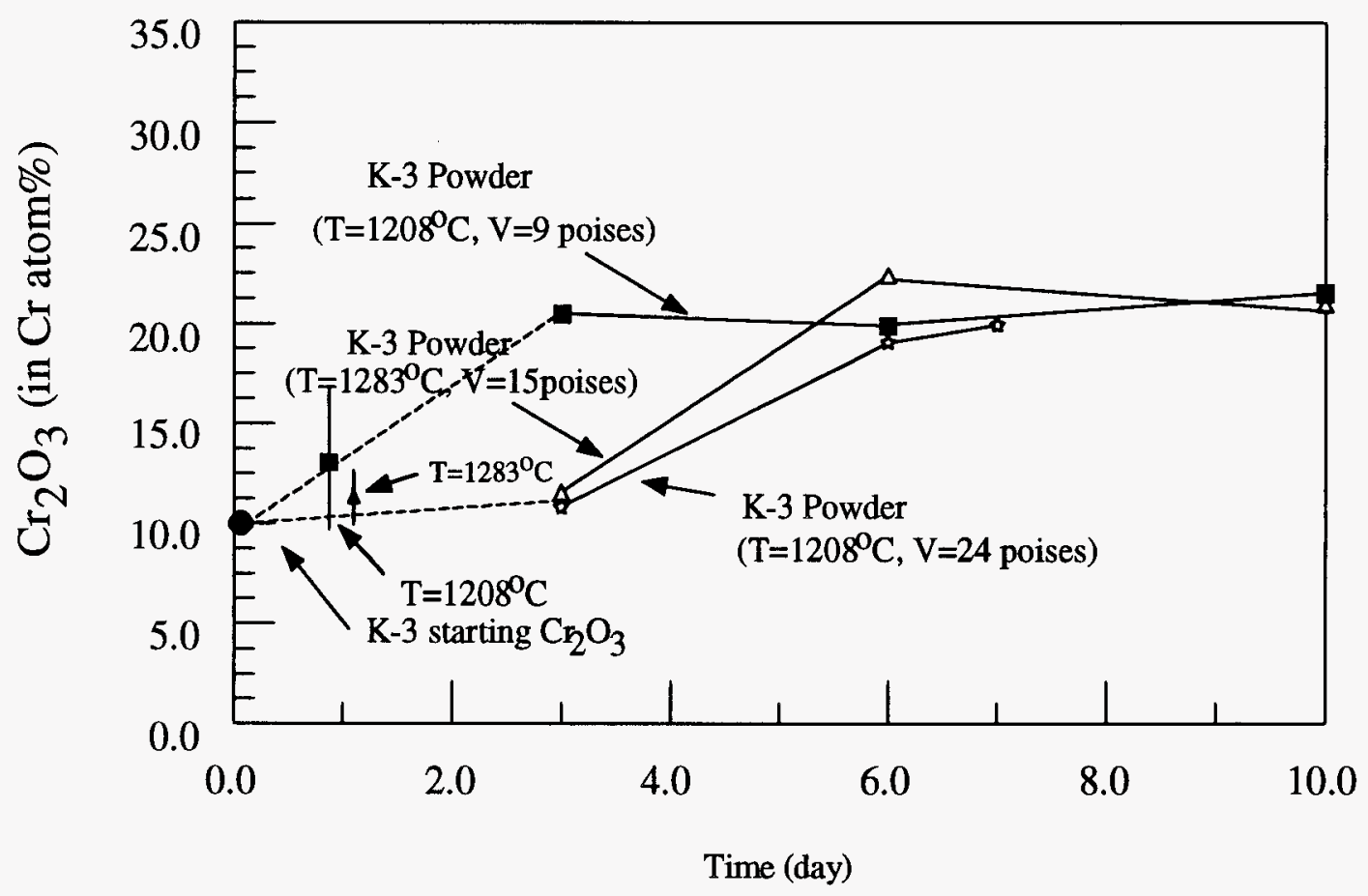

Figure 5.4. Effect of viscosity and temperature on time variation of interface spinel composition. $(\mathrm{V}=$ viscosity and $\mathrm{T}=$ temperature $)$ 


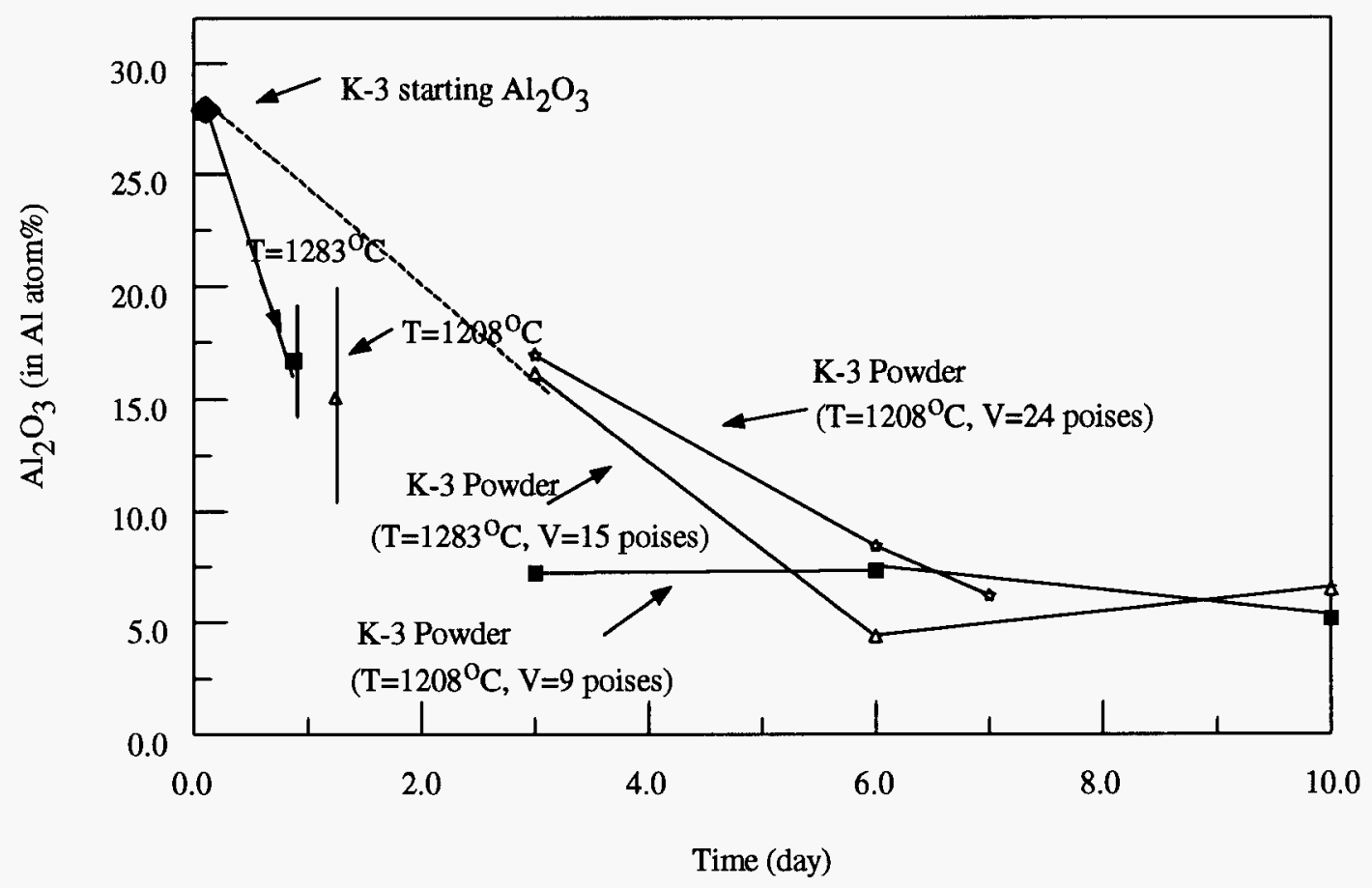

Figure 5.5. Effect of viscosity and temperature on time variation of interface spinel composition. $(\mathrm{V}=$ viscosity and $\mathrm{T}=$ temperature $)$ 
Normalized variation of $\mathrm{Cr}_{2} \mathrm{O}_{3} / \mathrm{Al}_{2} \mathrm{O}_{3}$

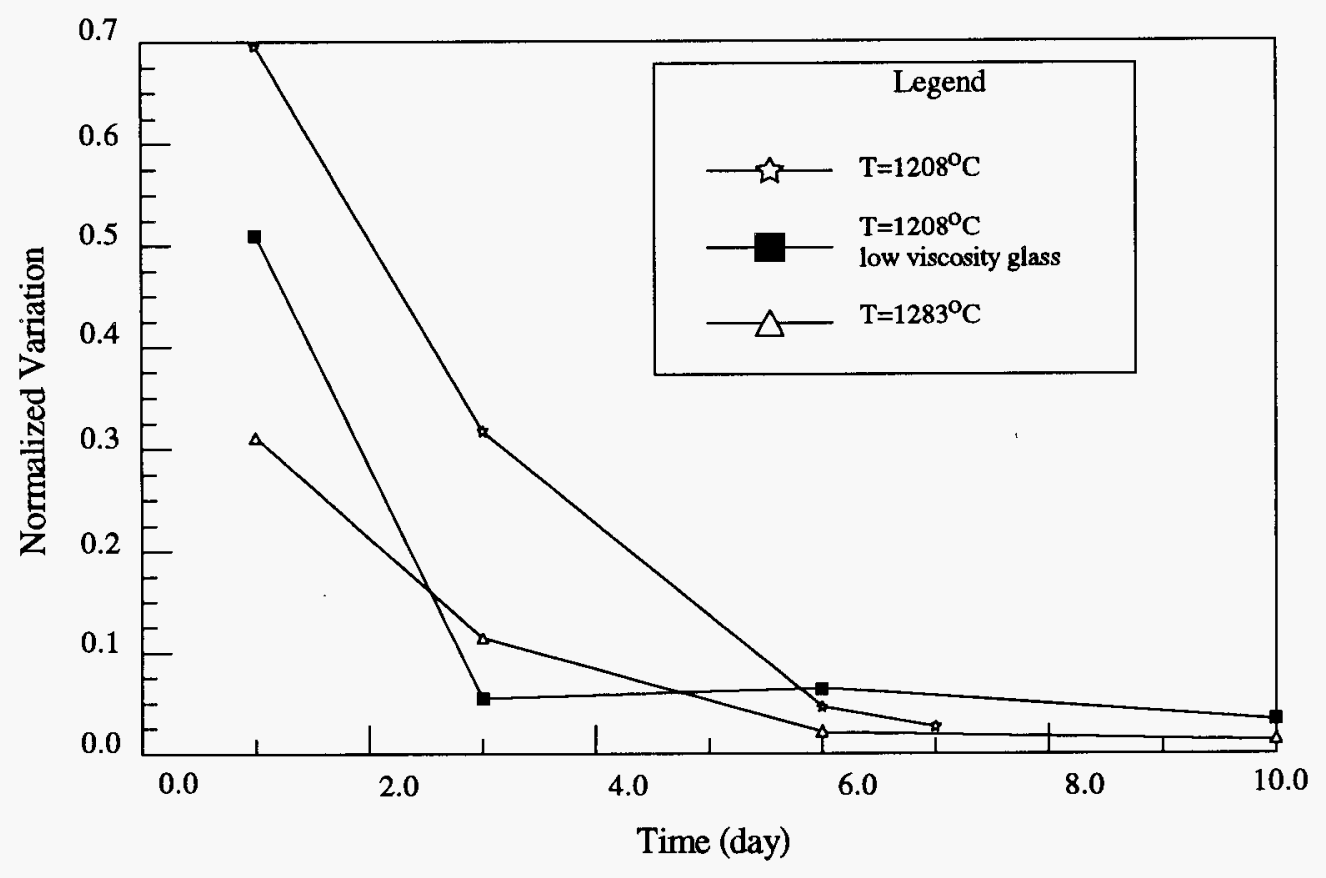

Figure 5.6. Effects of viscosity and temperature on the "normalized variation." 
a)

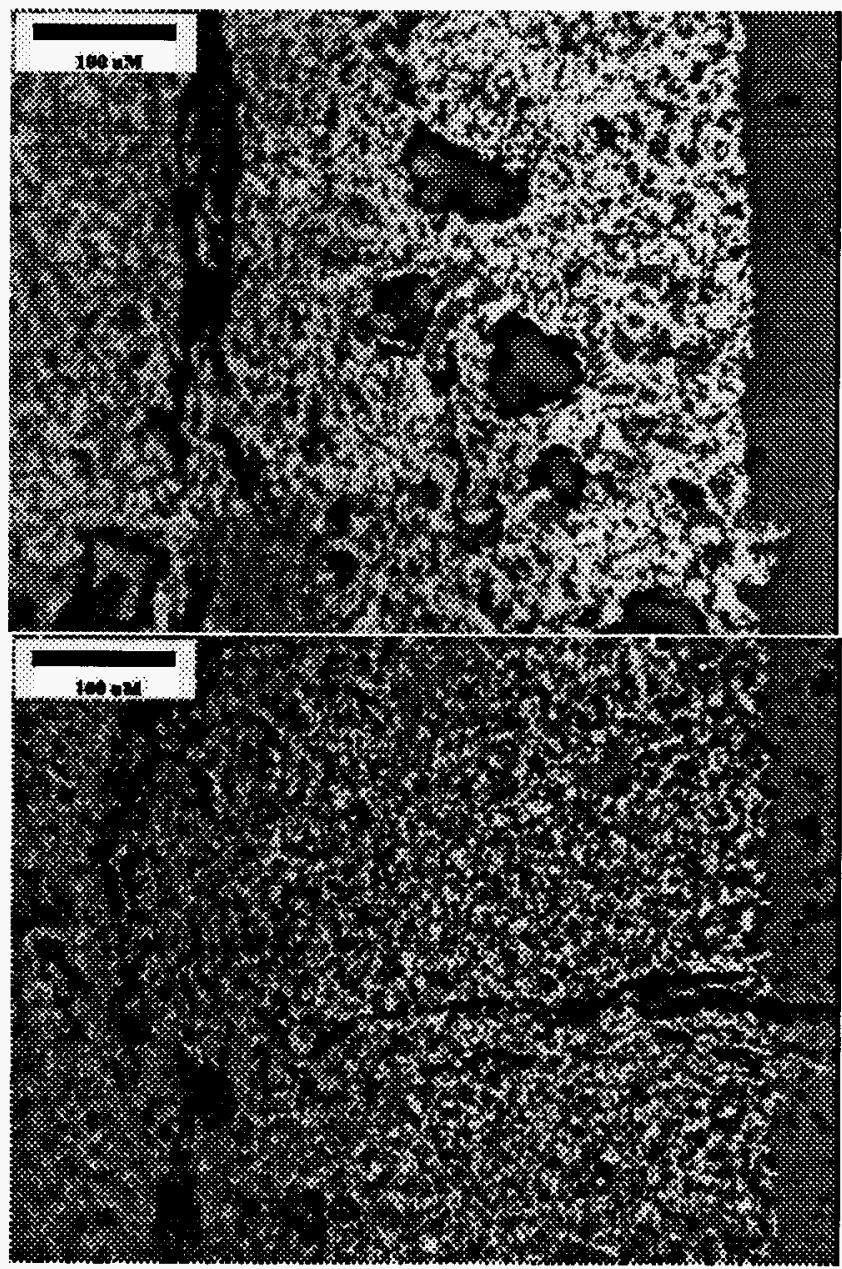

b)

c)

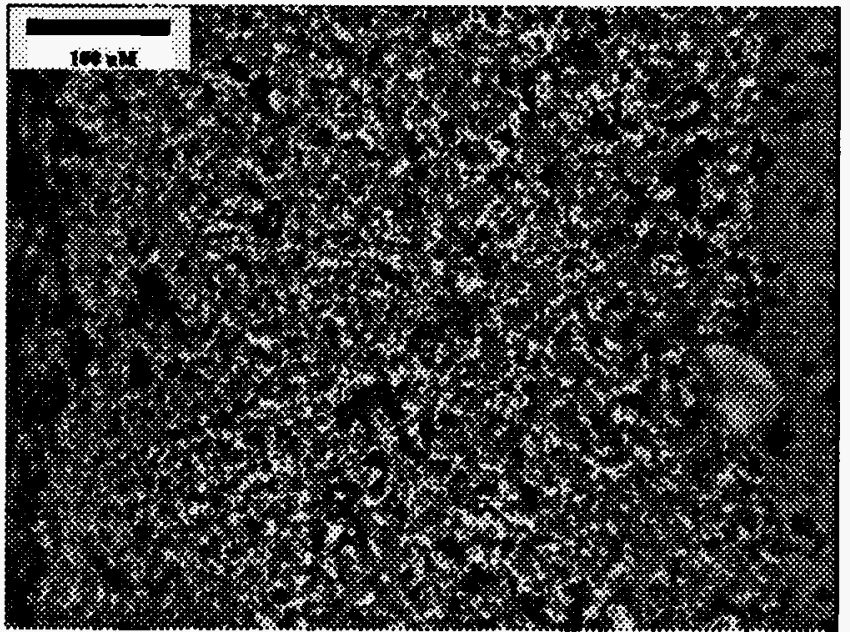

Figure 6.1 (a)-(c). Micrographs of $K-3$ coupons after six-day glass contact corrosion in, a) HLWD1-4SL at $1208^{\circ} \mathrm{C}$; b) HLWD1-4SH at $1283^{\circ} \mathrm{C}$; and c) HLWD4SH2R at $1389^{\circ} \mathrm{C}$. 
a)

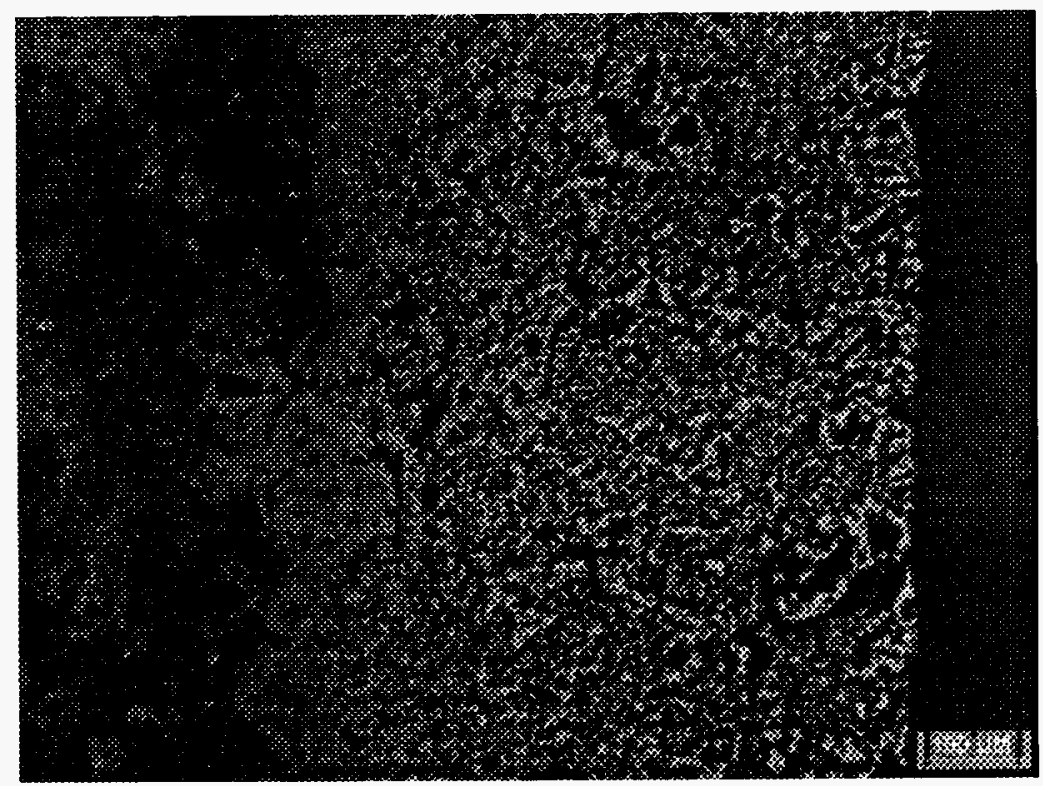

b)

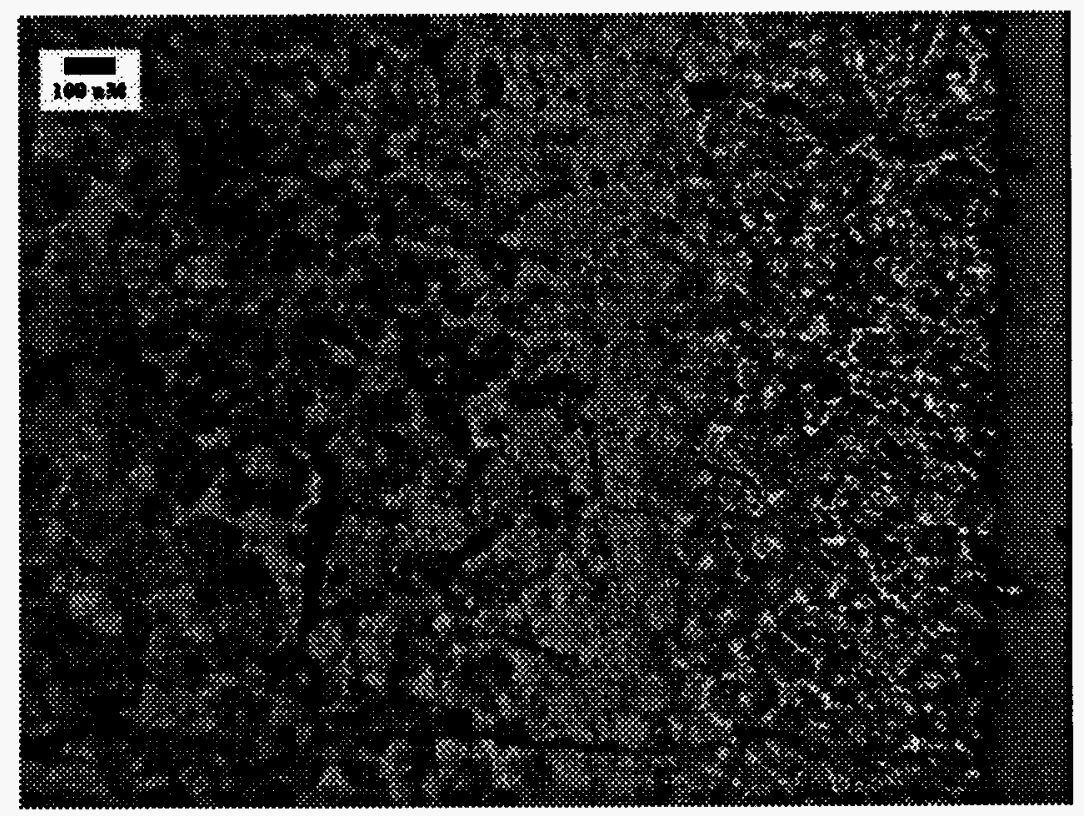

Figure 6.2. Micrographs of K-3 after six-day glass contact corrosion in, a) WVREF6 at $1208^{\circ} \mathrm{C}$; b) SRL-EA at $1208^{\circ} \mathrm{C}$. 